\title{
Systematic review of the European Gymnophora Macquart (Diptera: Phoridae), with five new species
}

\author{
R. Henry L. DISNEY \\ Department of Zoology, University of Cambridge, Cambridge CB2 3EJ, England; e-mail: rhld2@hermes.cam.ac.uk
}

\begin{abstract}
Five species of the genus Gymnophora, i.e. G. bifida n. sp., G. distinctus n. sp., G. forresteri n. sp, G. tyrolensis n. sp., G. winqvisti n. sp. are described. The new key to European species of the genus, richly illustrated with color photographs, is provided.
\end{abstract}

Key words: Diptera, Phoridae, Gymnophora, Europe, new species, key to species

\section{INTRODUCTION}

So far, only eight species of Gymnophora were known from Europe. A collection of Gymnophora Macquart (Diptera: Phoridae) sent by Kaj Winqvist from Finland prompted a revision of the European species of this genus when some failed to key out in the review by Mostovski \& Michailovskaya (2003).

\section{MATERIAL AND METHODS}

Specimens preserved in $70 \%$ ethanol have been remounted on slides in Berlese Fluid (Disney 2001). The specimens are deposited in Cambridge University, Museum of Zoology (CUMZ).

\section{SYSTEMATIC REVIEW}

Subfamily Metopininae

Tribe Gymnophorini

Genus Gymnophora Macquart

Gymnophora Macquart, 1835: 631

Capraephora Bezzi, 1922 (subgenus): 113

Cerocratia Schmitz, 1929 (subgenus): 133

More than sixty species are known. Both sexes of the British species were keyed by Disney (1983) and all the Palaearctic species by Mostovski \& Michailovskaya (2003) and with those of the Russian Far East also covered by Michailovskaya (2004a, b). Otherwise only males can be named in our present state of knowledge. The Nearctic species are keyed by Brown (1987a). The Neotropical species are keyed by Brown (1987b) and a species from the Falkland Islands, only known in the female sex is covered by Disney (2009). Oriental species are covered by Brown $(1989,1998)$ and Liu (2001), who covers Chinese species.

The male hypopygia are complex, especially the penis complex, and the hypandrium tends to be displaced to one side. More than one figure is often required to adequately illustrate a hypopygium. The species are therefore initially sorted on the basis of the details of the costa and thick veins of the wing, but these are a little more variable than previously supposed. 


\section{Gymnophora arcuata (Meigen)}

Phora arcuata Meigen, 1830: 222.

(Figs 1-4)

Trineura rufipes Fallén, 1823: 5 (part). Misidentification.

Phora debilis Haliday, 1833: 179.

A lectotype was designated by Mostovski \& Michailovskaya (2003).

Distribution. Widespread in British Isles. Mainland Europe: from Finland and France to Portugal and Spain; and eastwards to Germany, Hungary, Italy and Greece and Israel.

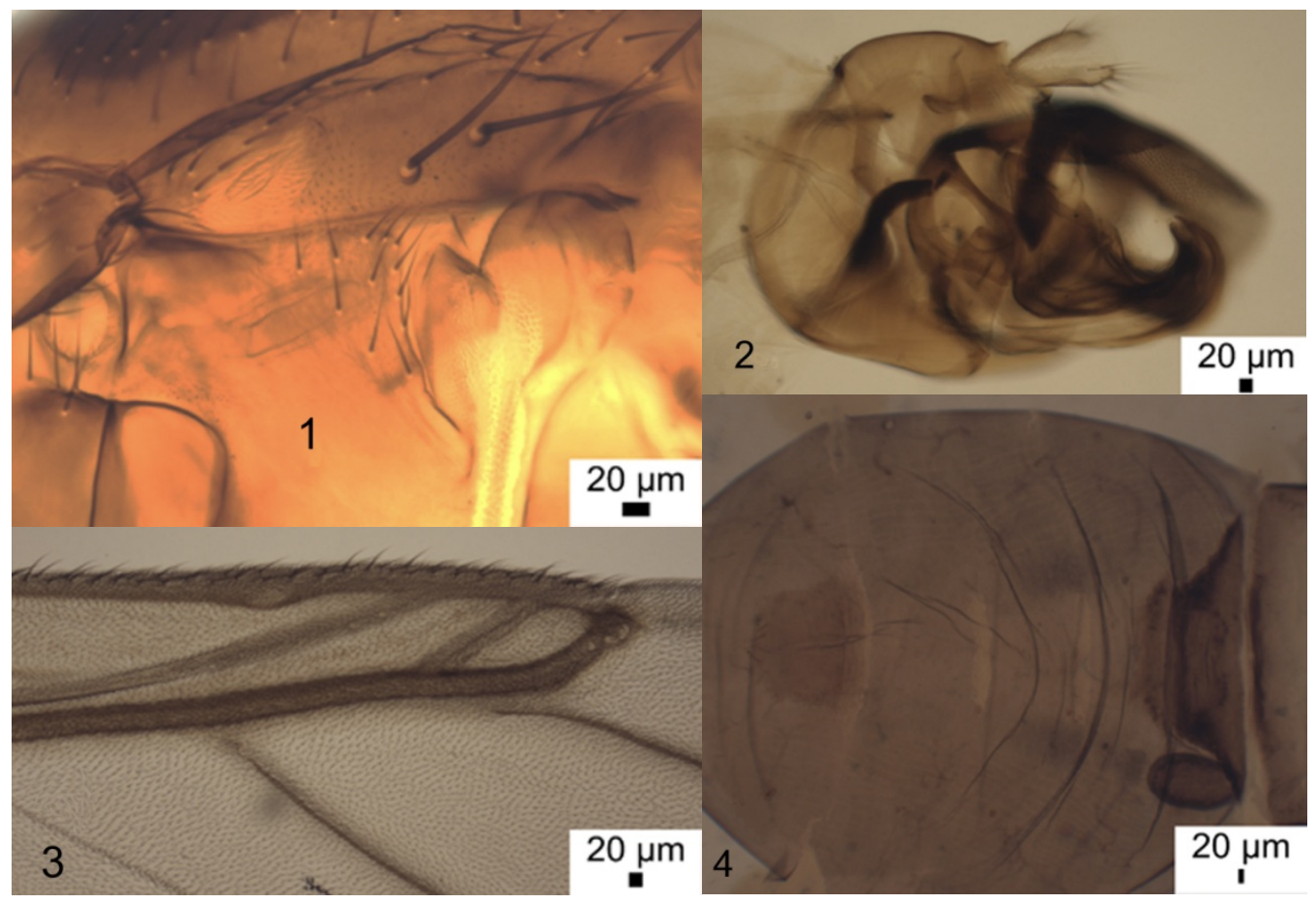

Figs 1-4. Gymnophora arcuata (Meigen). 1 - left face of male notopleuron and mesopleuron, 2 - left face of male hypopygium, 3 - Base of male wing, 4 - dorsalface of female abdominal segments 2 to 6 .

\section{Gymnophora bifida n. sp.}

(Figs 5-20)

Description. Male. Frons and postpedicels as Fig. 5. Proboscis and palps as Fig. 6. With 2 bristles on notopleuron and the oblique ridge covering the orifice of the duct from the notopleural gland is black. Scutellum with anterior hairs $0.07 \mathrm{~mm}$ long and the posterior pair of more robust hairs $0.11 \mathrm{~mm}$ long. Abdominal tergites brown. Venter grayish brown with hairs on segment 6. Hypopygium as Figs 7-11. Legs brown. Front tarsus as Fig. 12. Hind femur and tibia as Fig. 13. Basal region of wing as Fig. 14. Wing length 2.64-2.67 mm. Costal index 0.48-0.50. Costal ratios 7.4-7.6 : 1.9-2.1 : 1. Haltere knob light brown.

Female. Frons as Fig. 15. Postpedicels, palps and proboscis as Fig. 16. Dorsal abdominal glands as Fig. 17. Tergite 7 as Fig. 18. Sternite 8 as Fig. 19. Legs similar to male but paler. Wing (Fig. 20) length $2.63 \mathrm{~mm}$. Costal index 0.44. Costal ratios $9.8: 2.6: 1$. Haltere as male but paler. 

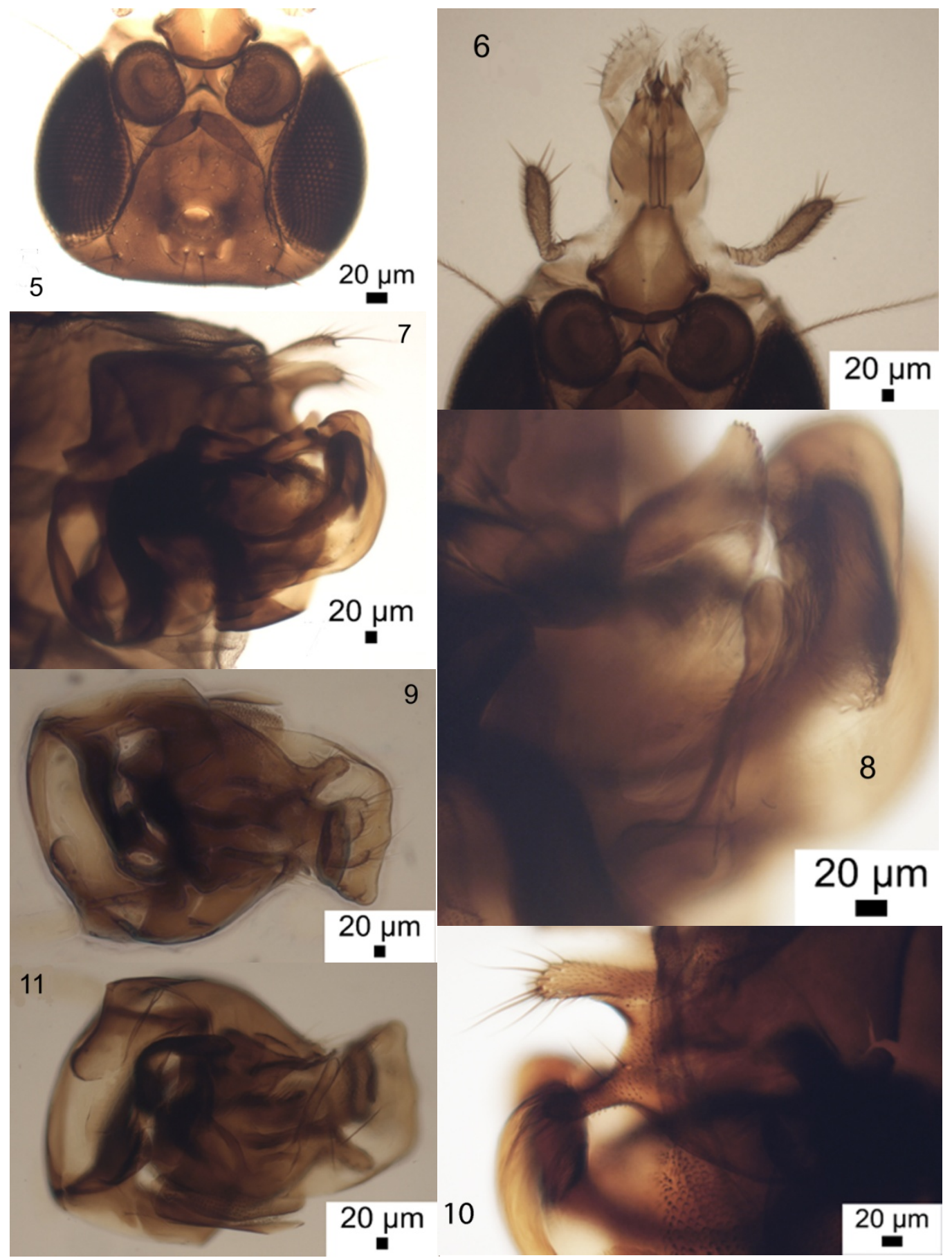

\section{0}

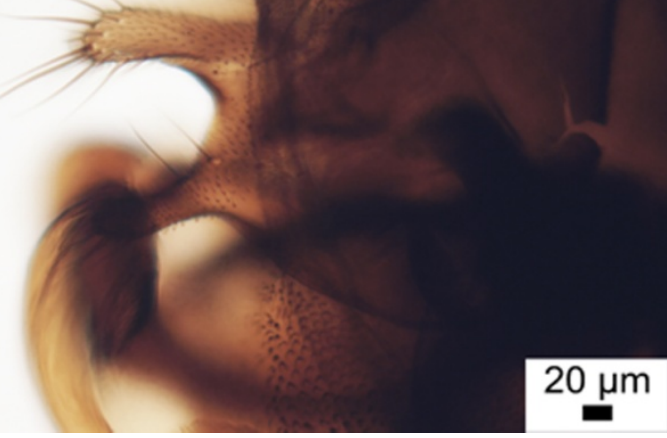

Figs 5-11. Gymnophora bifida n. sp. male. 5 - frons and postpedicels; 6 - proboscis and palps; 7-11 - hypopygium: 7 - left face, 8 - penis complex and left process of hypandrium, 9 - dorsal face; 10 - right face of epandrium, 11 - ventral face. 


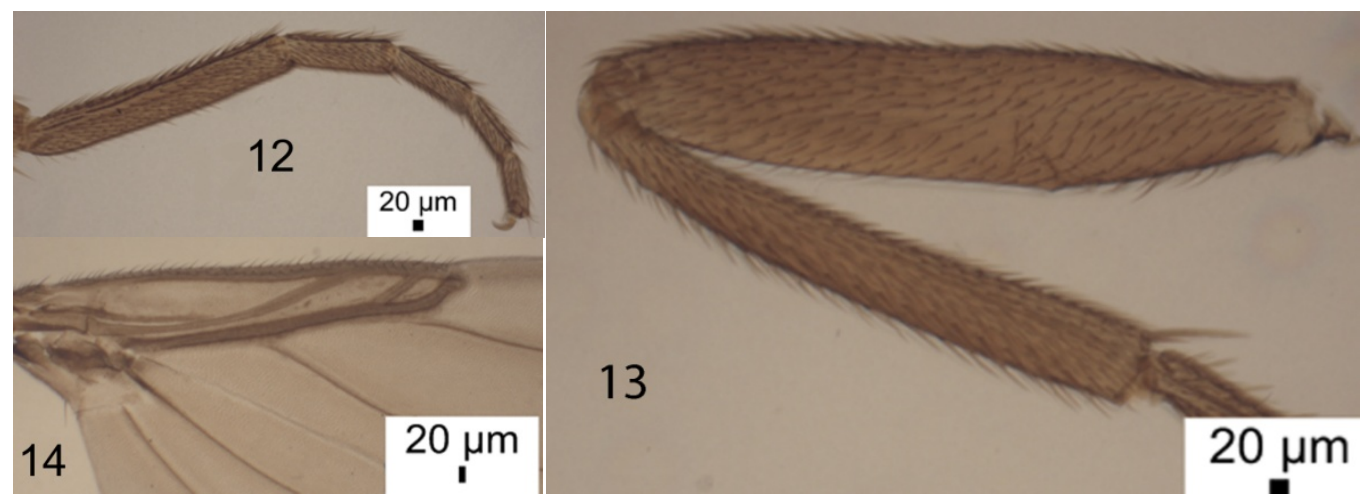

Figs 12-14. Gymnophora bifida n. sp. male. 12 - front tarsus, 13 - hind femur and tibia, 14 - basal region of wing.

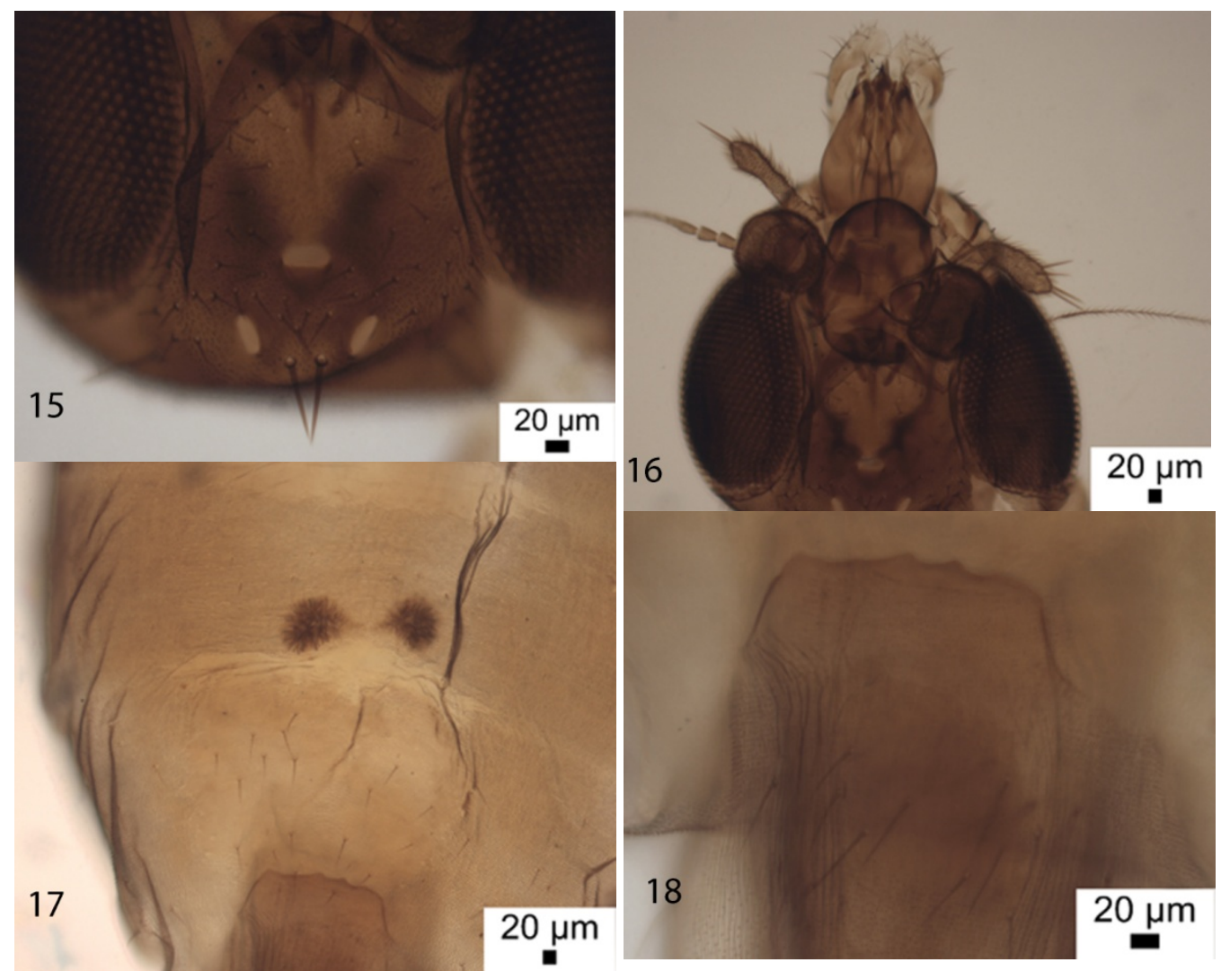

Figs 15-18. Gymnophora bifida n. sp. female. 15 - frons, 16 - postpedicels, palps and proboscis, 17 - dorsal abdominal glands of abdomen, 18 - abdominal tergite 7.

Material examined. Holotype male, Finland Lkor: Savakoski. Yli-Nuorti 7524114: 3599141, 30 Jul-28 Sep 2015, Kaj Winqvist (CUMZ 34-188). Paratypes, male, and female, as holotype (CUMZ 34-191). 
Etymology. Named after the right cercus and posteroventral process of the epandrium giving a bifid appearance to the male hypopygium.

Affinities. In the key by Mostovski \& Michailovskaya (2003) it seemingly runs to couplet 17 , but its highly distinctive hypopygium differs from all the species covered by their key.

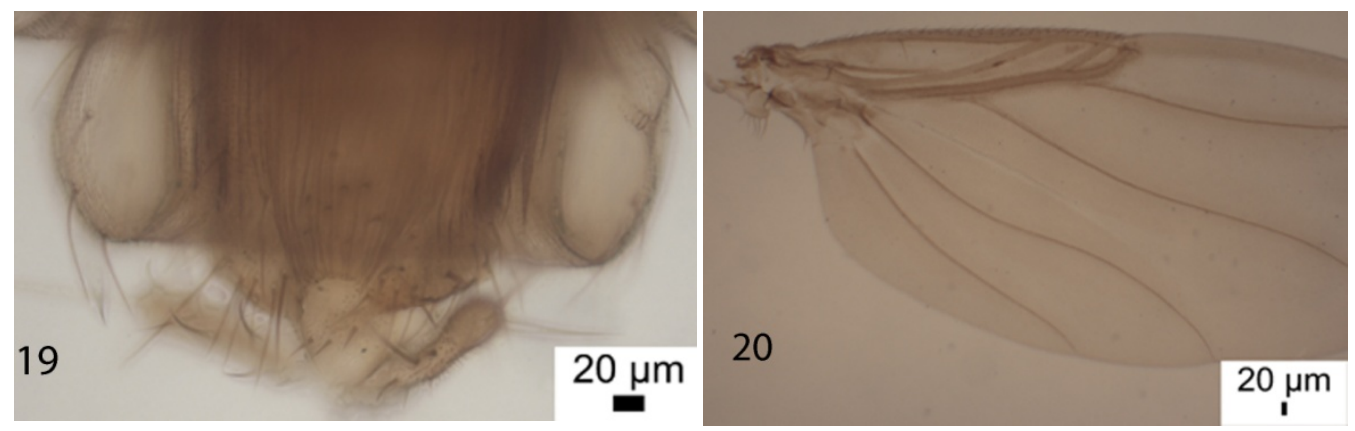

Figs 19-20. Gymnophora bifida n. sp. female. 19 - sternite 8, 20 - wing.

\section{Gymnophora distinctus n. sp.}

(Figs 21-28)

Male. Frons as Fig. 21. Postpedicels brown with numerous SPS vesicles that are variable in size (Fig. 22). Palps light brown with 3 bristles and a dozen hairs. Labrum twice as wide as postpedicel and its length 1.7 times its breadth. Thoracic notopleuron and mesopleuron as Fig. 23. Scutellum with anterior bristles $0.12 \mathrm{~mm}$ long and posterior pair $0.13 \mathrm{~mm}$ long. Abdominal tergites brown. Venter gray with hairs on segment 6. Hypopygium as Figs 24 \& 25, with hypandrium as Fig. 26. Legs brown but front legs paler. Front tarsus as Fig. 27. Wing $2.2 \mathrm{~mm}$ long with base as Fig. 28. Costal index 0.50. Costal ratios $6.3: 1.1: 1$. Haltere brown.

Material examined. Holotype male, Finland, Lkor: Savakoski. Yli-Nuortti 78424130: 359092, 30 Jul-28 Sep 2015, Kaj Winqvist (CUMZ 34-188).

Etymology. The name refers to the distinctive male hypopygium.

Affinities. In the key by Mostovski \& Michailovskaya (2003) it runs to couplet 9, where the hypopygium differs from both options.

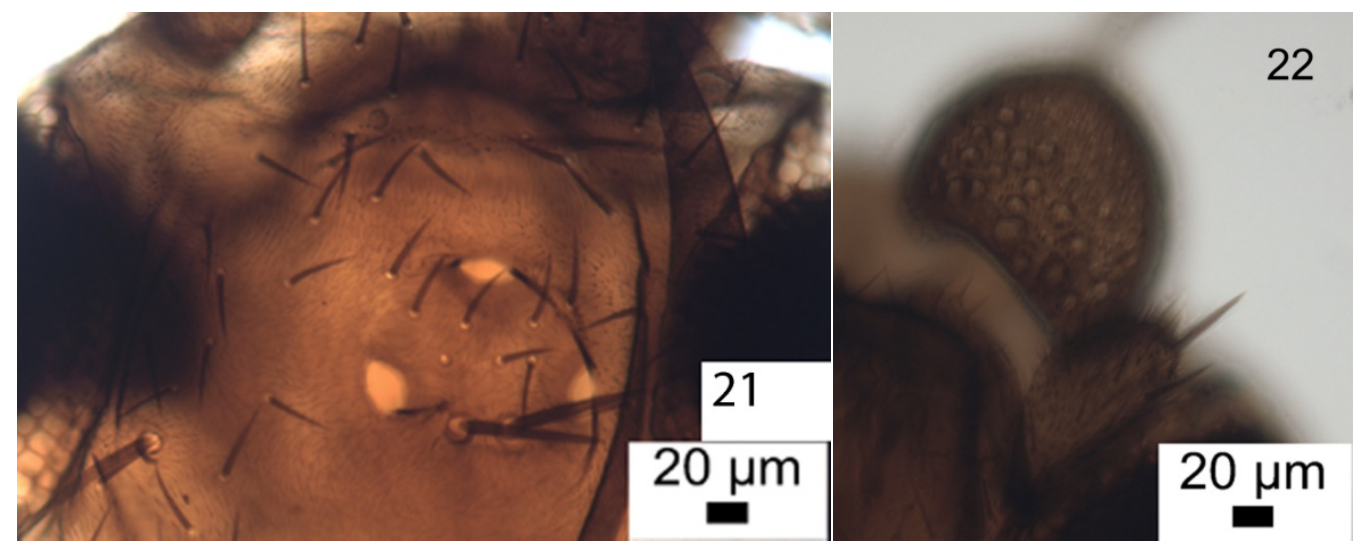

Figs 21-22. Gymnophora distinctus n. sp. male. 21 - frons, 22 - postpedicel, 


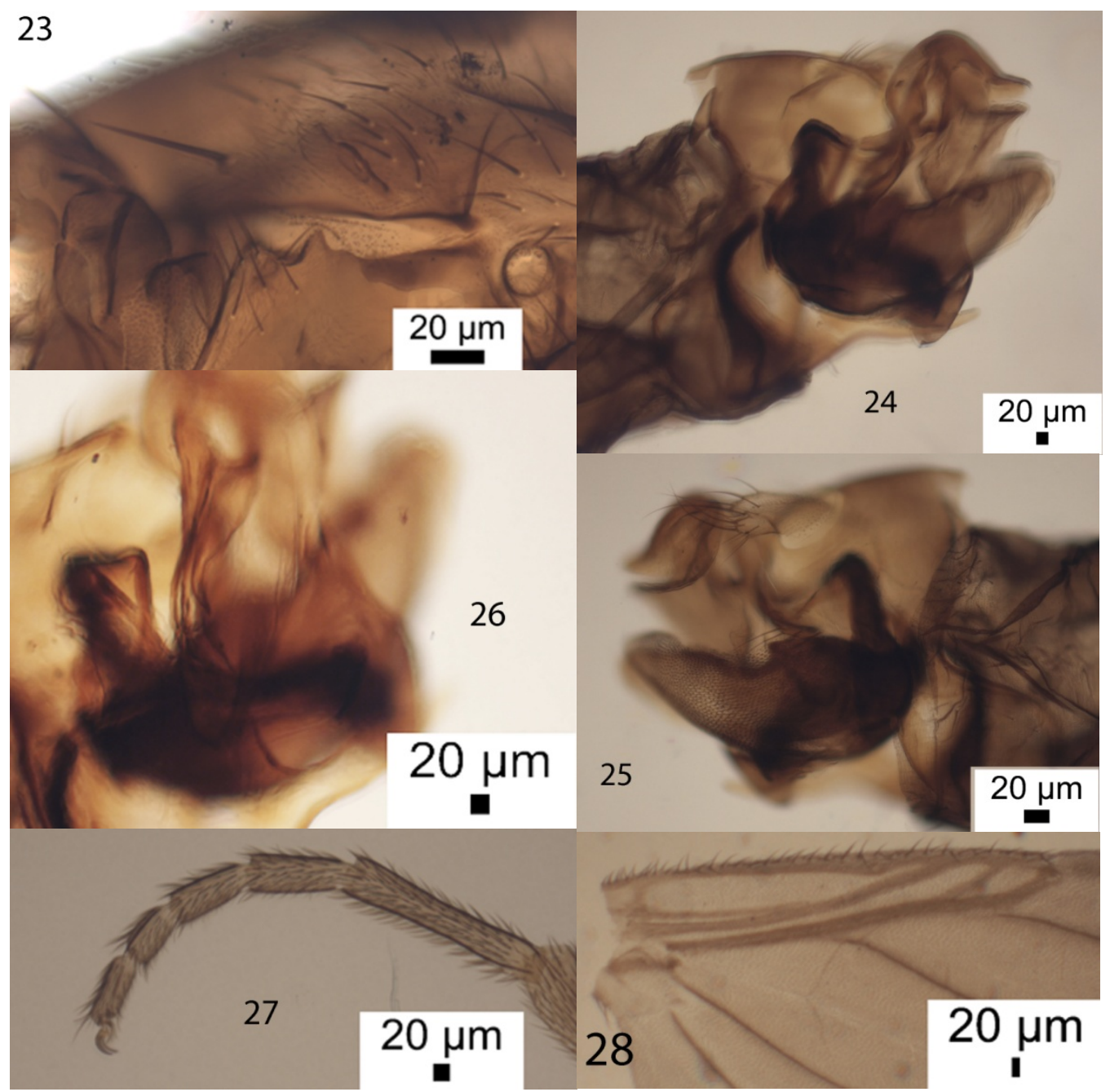

Figs 23-28. Gymnophora distinctus n. sp. male. 23 - thoracic notopleuron and mesopleuron, 24 - left face of hypopygium, 25 - right face of same, 26 - hypandrium, 27 - front tarsus; 28 - basal half of wing.

\section{Gymnophora forresteri n. sp.}

(Figs 29-47)

Gymnophora quartomollis Schmitz, 1920: 134 (female only); Disney 1983: 24 (female only); Disney \& Russell-Smith 2015 a, b (female only); Mostovski \& Michailovskaya 2003: 160 (female only).

The large series of males and females of G. quartomollis from Finland (see below) has allowed the recognition of the previous incorrect association of the females of this species with the males of $G$. quartomollis.

Description. Male. Frons with 0-2 small mediolateral bristles (Fig. 29). Postpedicels and palps as Fig. 30. With 2 bristles on the notopleuron and the oblique ridge with its posterior border black. Scutellum with the 4 bristles the anterior pair about $0.10 \mathrm{~mm}$ long and the posterior pair about $0.11 \mathrm{~mm}$ long. Abdominal tergites brown. Venter gray with conspicuous hairs on segment 6 but those on 3-5 greatly reduced in size. Hypopygium as Figs 31-35. Legs brown. Front tarsus 
(Fig. 36) with a posterodorsal hair palisade on segments 1 to 5. Hind leg as Fig. 37. Wing (Fig. 38) 2.1-2.5 mm long. Costal index 0.44-0.46. Costal ratios 5.9-11.1 : 1.1-2.4 : 1. Haltere knob gray. Female. Head as Fig. 39. Anterior scutellar bristles $0.11 \mathrm{~mm}$ long, posterior pair 0.13 mm. Abdominal tergites 5 and 6 as Fig. 40. Tergites 7 and 8 as Figs $41-42$. T8 as Fig. 43. Sternite 7 and tip of sternum 8 as Fig. 44. Front tarsus with posterodorsal hair palisades on segments 1-5 (Fig. 45). Hind leg as Fig. 46. Wing (Fig. 47) 2.5-3.1 mm long. Costal index $0.43-0.44$. Costal ratios 6.7-12.9 : 1.2-1.8: 1 . Haltere as male.

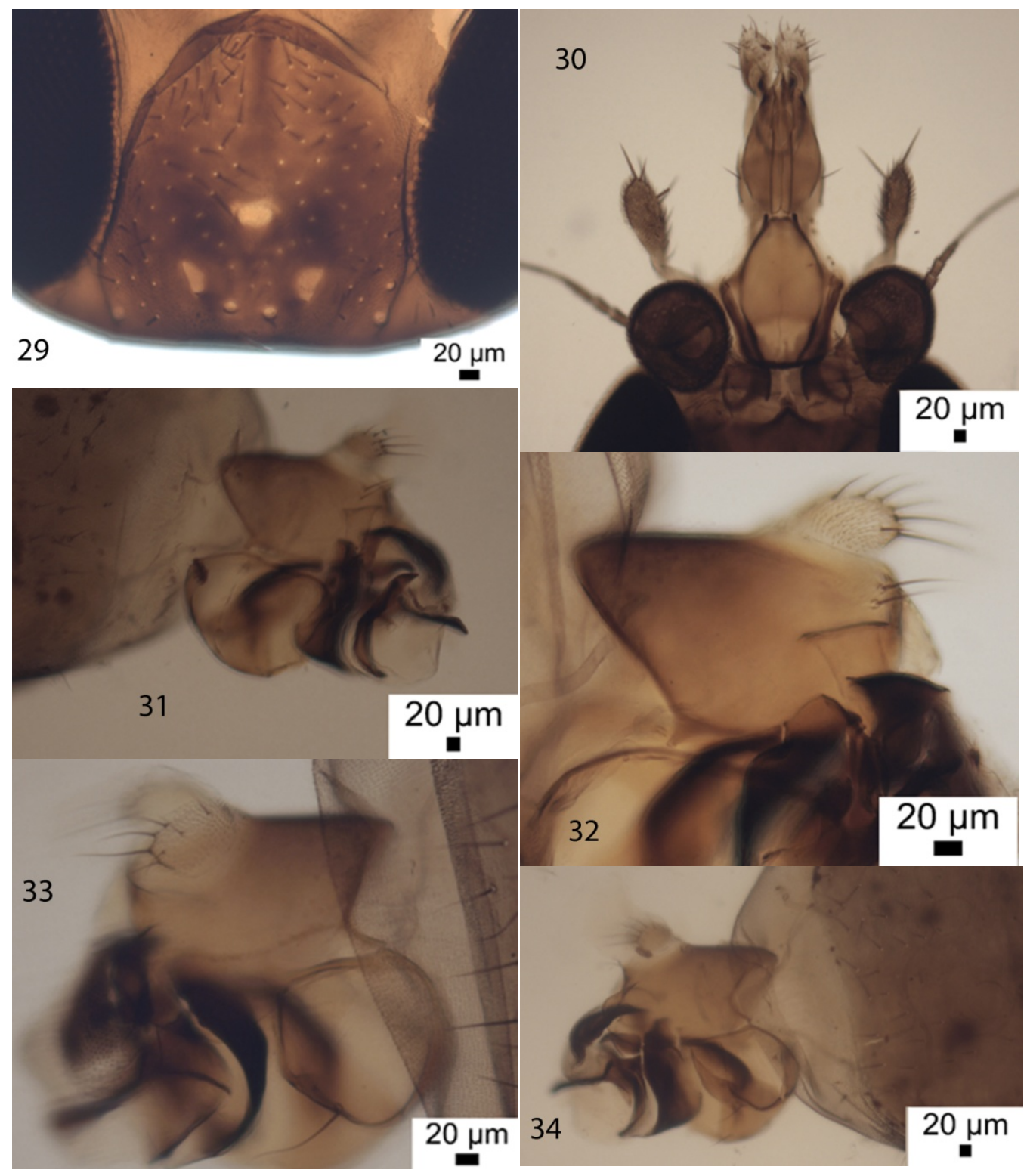

Figs 29-34. Gymnophora forresteri n. sp. male. 29 - frons, 30 - postpedicels, proboscis and palps, 31 - left face of hypopygium, 32 - left face of epandrium, 33 - process from left edge of hypandrium, 34 - right face of hypandrium. 


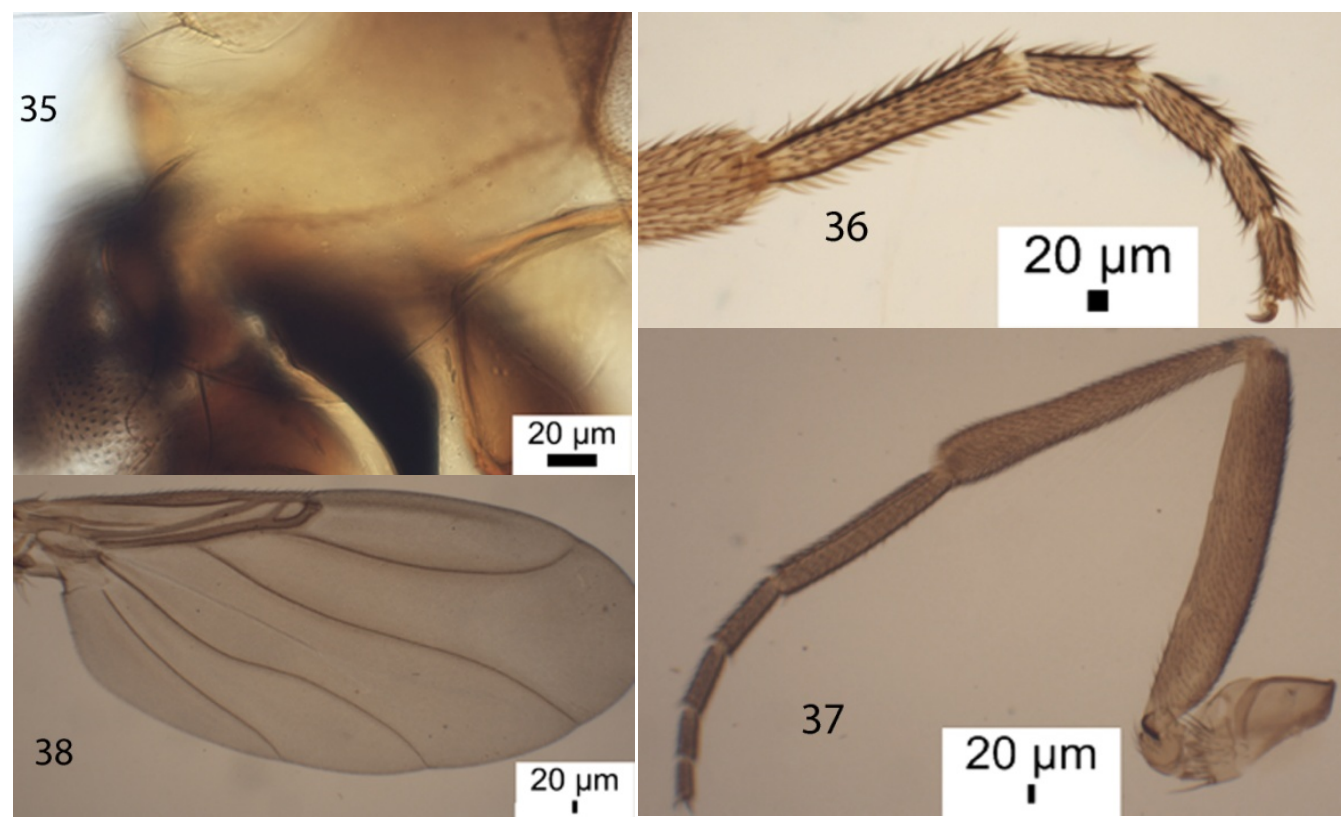

Figs 35-38. Gymnophora forresteri n. sp. male. 35 - right face of epandrium, 36 - front tarsus, 37 - hind leg, 38 wing.

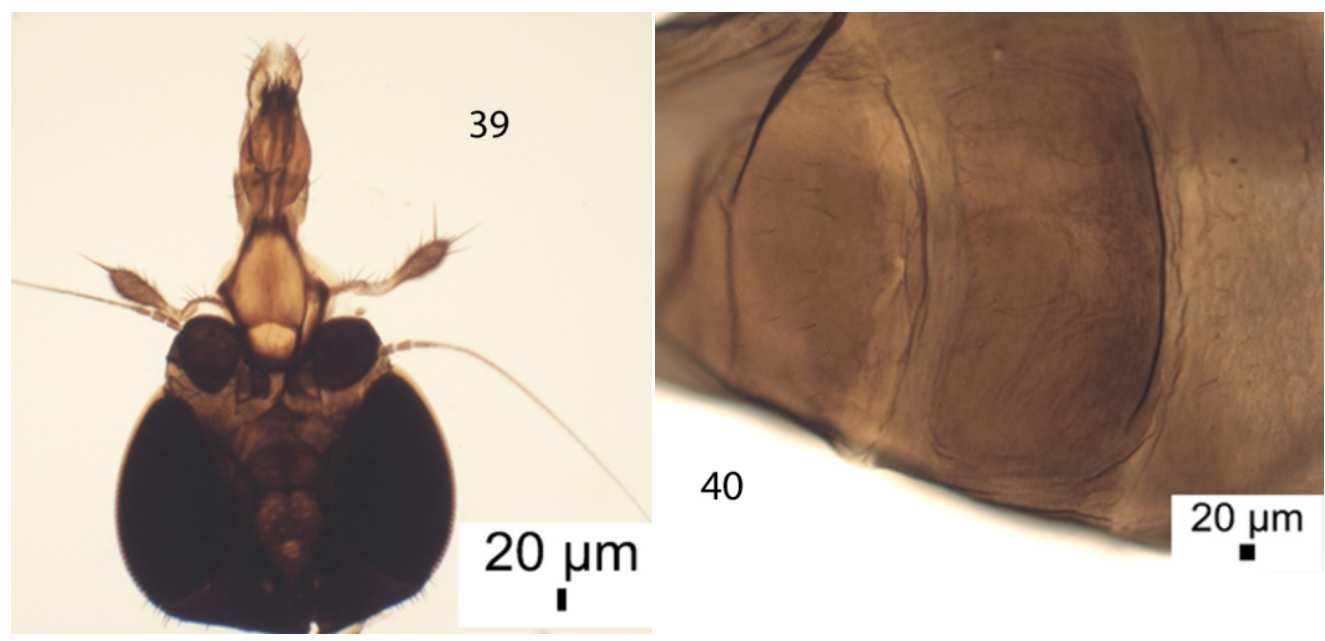

Figs 39-40. Gymnophora forresteri n. sp. female. 39 - head, 40 - abdominal tergites 5 and 6.

Material examined. Holotype male, England: Hampshire, New Forest, Baker's Meadow, grid ref. 41/390031, Jun 1984, G. Forrester (CUMZ 13-69). Paratypes: 1 male as holotype; 2 males, 1 female, Isle of Wight, Walter's Copse, 2 Jul 1980, P. Chandler (CUMZ 8180); 6 males, 3 females, Herefordshire, Moccas Park NNR, grid ref. 3442, 5 Jun-10 Jul 1992, J. Cooter (CUMZ 8-176-178); 1 male, 1 female, Berkshire, Windsor Great Park, from the crown of an ancient pollarded oak tree (Quercus sp.), 16 May-22 Jun 2012, A. Russell-Smith (CUMZ 22-97); 1 female, Essex, Hatfield Forest, in crown of an ancient hornbeam tree 
(Carpinus betulus), 25 May-22 Jun 2011, A. Russell-Smith (CUMZ 22-101); 1 female, Gloucestershire, Cannop Ponds, 32/609107, 19 Jul 1980, I. McLean (CUMZ 7-28); 1 female, Oxfordshire, Bagley Wood, from canopy of oak (Quercus robur), 1980-1984, S. Greenwood (UCZM 19-21); 1 female, Havering, Dagnam Park, 51/5509390, 11 Jul 1980, D. A. Smith (UCZM 7-149); 1 female, Essex, Laindon, 51/685882, 5 Aug 1979, D. A. Smith (UCZM 4-139).

Etymology. Named after G. Forrester, the collector of the holotype.

Affinities. In the key by Mostovski \& Michailovskaya (2003) it runs to G. quartomollis. The two species are distinguished in the key below.

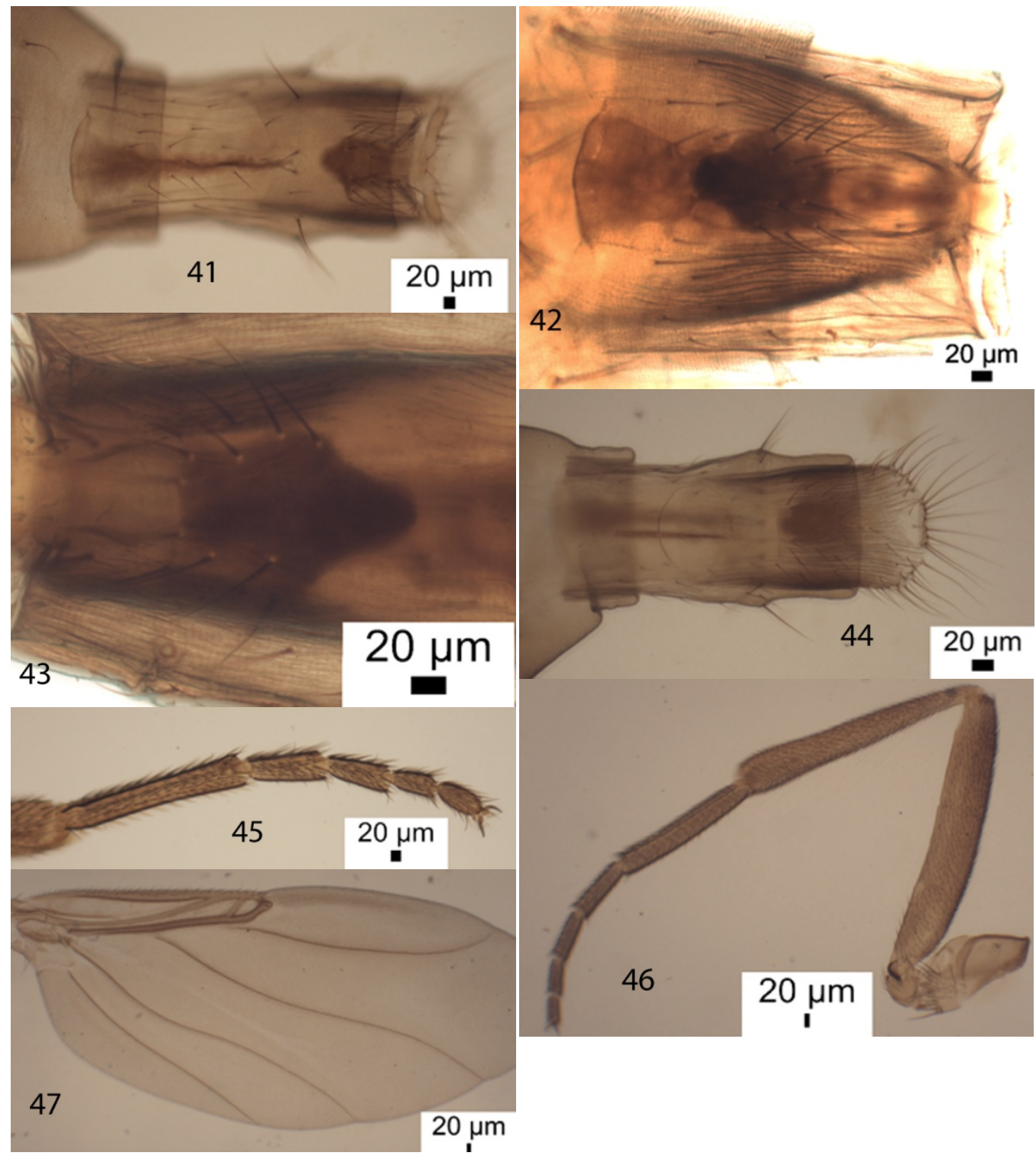

Figs 41-47. Gymnophora forresteri n. sp. female. 41-42 - tergites 7 and 8, 43 - tergite 8, 44 - sternite 7 and tip of sternum 8, 45 - front tarsus, 46 - hind leg, 47 - wing. 


\section{Gymnophora healeyae Disney}

(Figs 48-53)

Gymnophora healeyae Disney, 1980: 125.

Distribution. England: Cumbria, Durham, North Yorkshire, Suffolk. Mainland Europe: Finland, Italy.
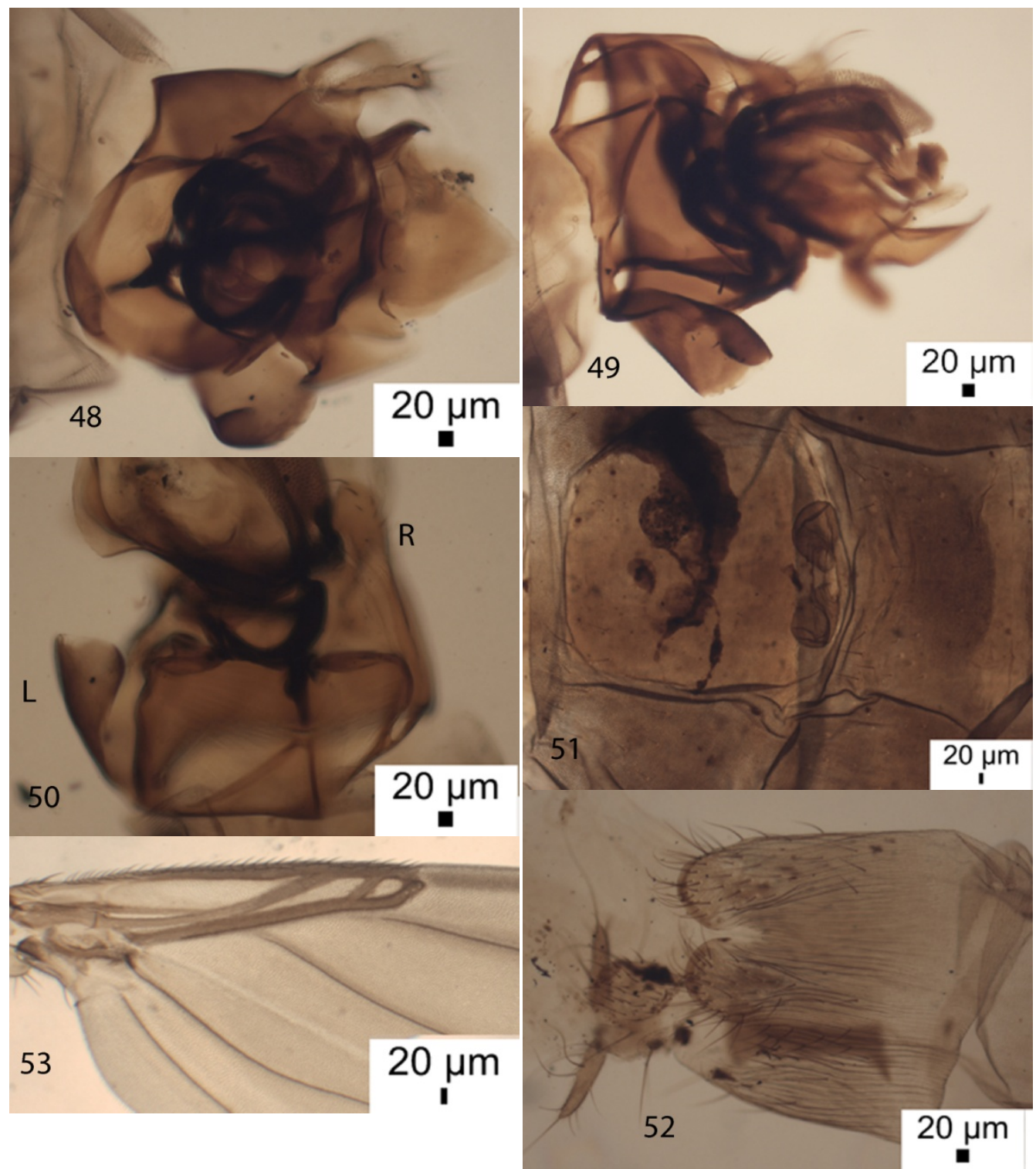

Figs 48-53. Gymnophora healeyae Disney. 48-50 - male hypopygium ( $\mathrm{L}$ and $\mathrm{R}=$ processes from edges of hypandrium), 51 - female abdominal tergites 5-6 and dorsal abdominal glands, 52 - lobes at rear of female sternum 8 , 53 - basal part of female wing. 


\section{Gymnophora integralis Schmitz}

(Figs 54-59)

Gymnophora integralis Schmitz, 1920: 133 (female).

Distribution. England: Gloucestershire. Mainland Europe: from Sweden to France, Italy and Spain, and eastwards to Bulgaria, Hungary and Romania. Russian Far East and Japan.

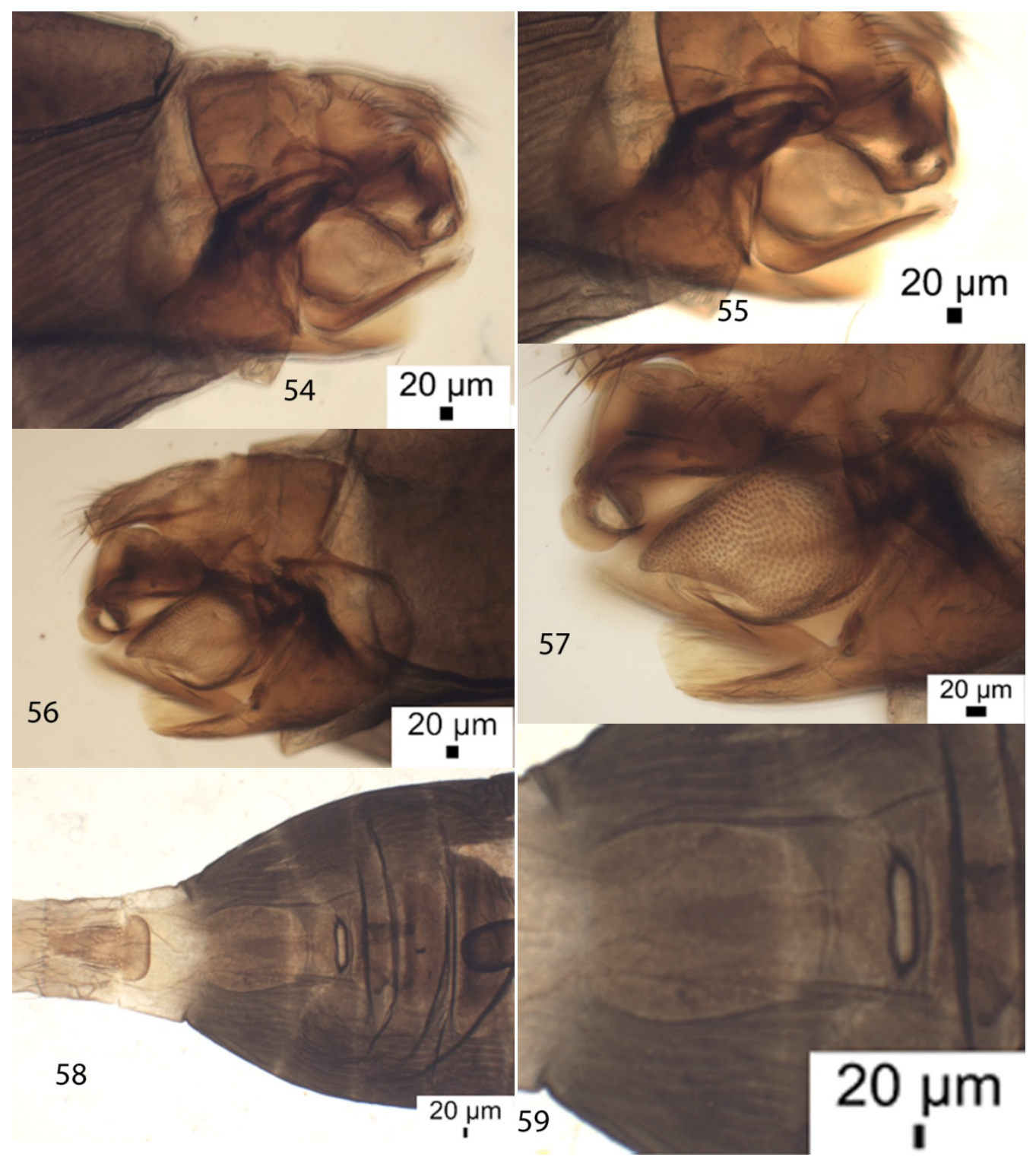

Figs 54-59. Gymnophora integralis Schmitz. 54-57 - male hypopygium, 58-59 - female abdominal tergites 5-7 plus chamber embracing orifice of dorsal abdominal glands. 


\section{Gymnophora lapidicola (Bezzi)}

(Figs 60-62)

Capraephora lapidicola Bezzi, 1922: 116 (male).

Gymnophora lapidicola (Bezzi): Ghidini 1934: 131 (female).

Distribution. This montane species was re-described by Disney (2015). So far known from Italy.
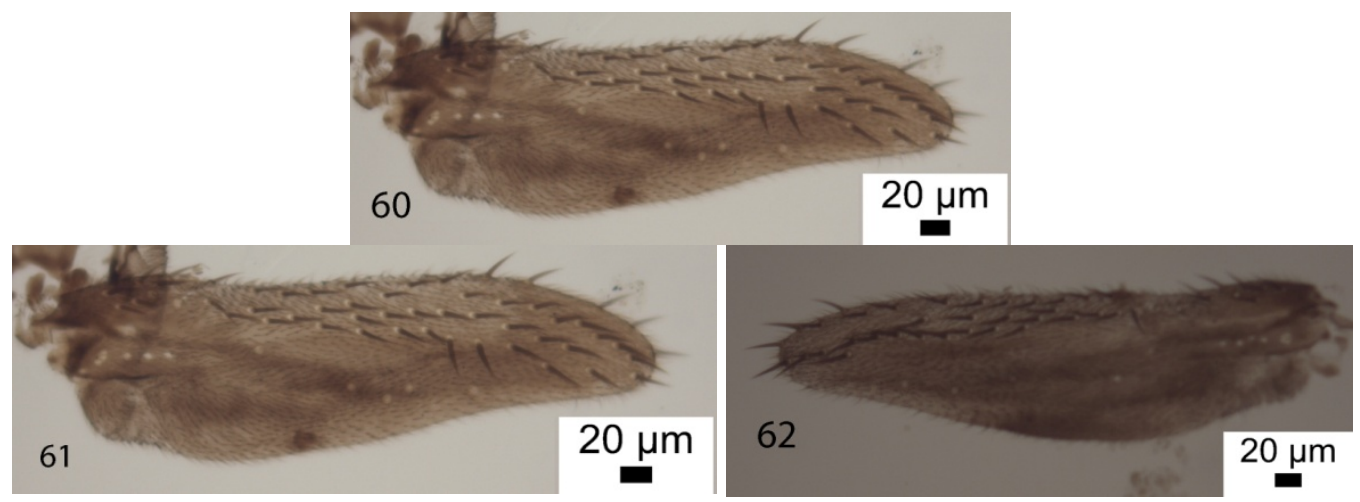

Figs 60-62. Gymnophora lapidicola (Bezzi) wings. 60 - male, 61-62 - female.

\section{Gymnophora nigripennis Schmitz}

(Fig. 63)

Gymnophora nigripennis Schmitz, 1926: 21.

Gymnophora fuliginosa Meigen, 1830: Schmitz, 1920: 133, fig.11.

Not Gymnophora fuliginosa (Meigen, 1830): Schmitz, 1952: 376.

A

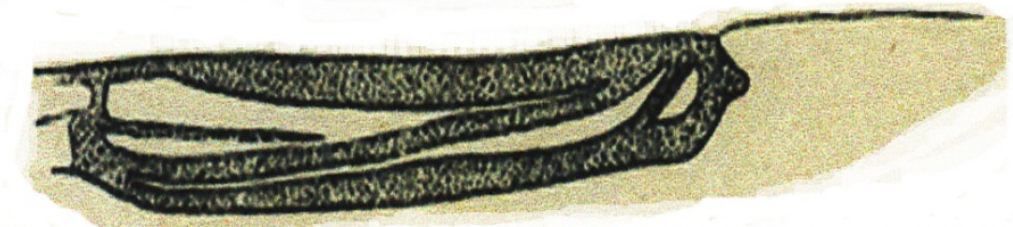

B

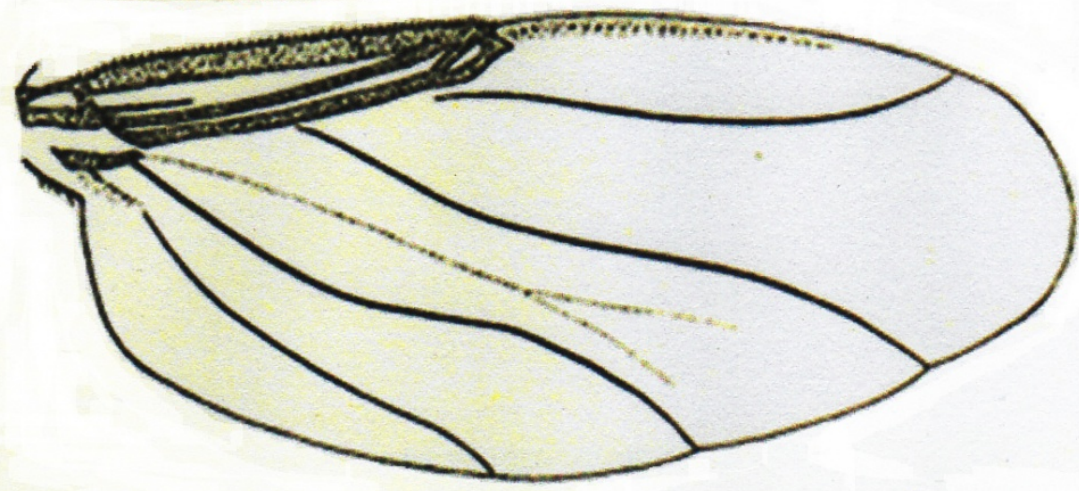

Fig. 63. Gymnophora nigripennis Schmitz wing. A - thick veins after Schmitz 1920; B - wing after Lundbeck 1922. 
Mostovski \& Michailovskaya (2003) commented that "the recognition of this species is probably the most troublesome in the genus”. It seems they overlooked the figures of the wing of its synonym G. fuliginosa, Fig. 11 at the end of Schmitz (1920) that I reproduce here as Fig. 63A along with that of Lundbeck (1922) (Fig. 63B). This is clearly the most distinctive wing in the genus. Thus the specimens assigned to this species by Mostovski \& Michailovskaya (2003), and doubtless by others also, were evidently misidentified.

Distribution. The type locality is The Netherlands and Lundbeck (1922) recorded it from Denmark. It is supposedly known from northern Europe from Finland, Sweden to Austria, Italy, Hungary and eastwards to Czech Republic and Romania. These records require confirmation.

\section{Gymnophora perpropinqua Mostovski \& Mikhailovskaya}

(Figs 64-67)

Gymnophora perpropinqua Mostovski \& Mikhailovskaya, 2003: 78.

Distribution. Known from Crimea, Russia and Ukraine.

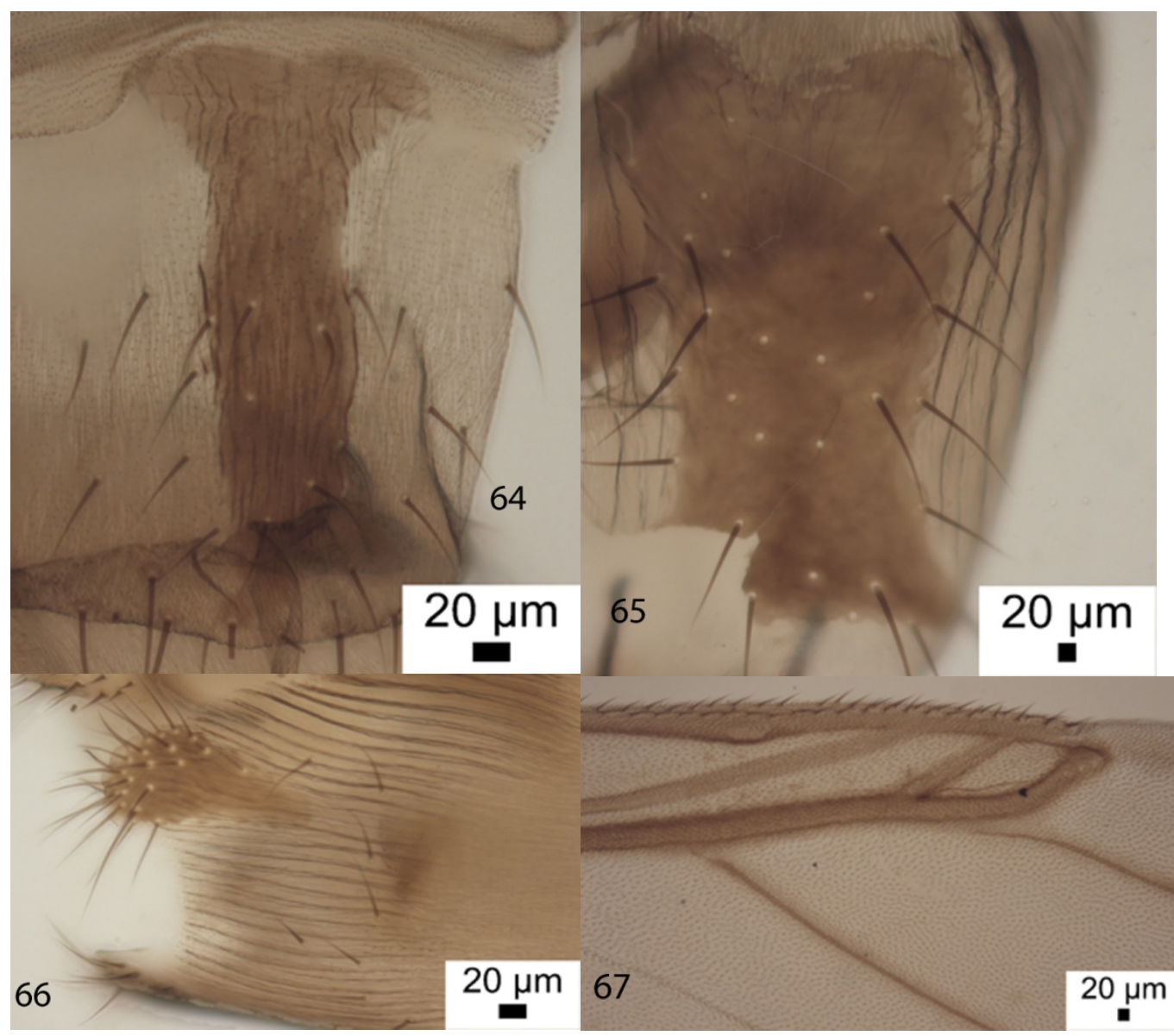

Figs 64-67. Gymnophora perpropinqua Mostovski \& Mikhailovskaya female. 64 - abdominal tergite 7, 65 - tergite 8, 66 - lobes at rear of sternum 8, 67 - distal portions of thick veins of wing. 


\section{Gymnophora prescherweberae Disney}

(Figs 68-78)

Gymnophora prescherweberae Disney, 1997: 133

Gymnophora laciniata Michailovskaya, 1997: 7; Mostovski \& Michailovskaya 2003: 159.

Distribution. Known from Austria, Germany and the Russian Far East.
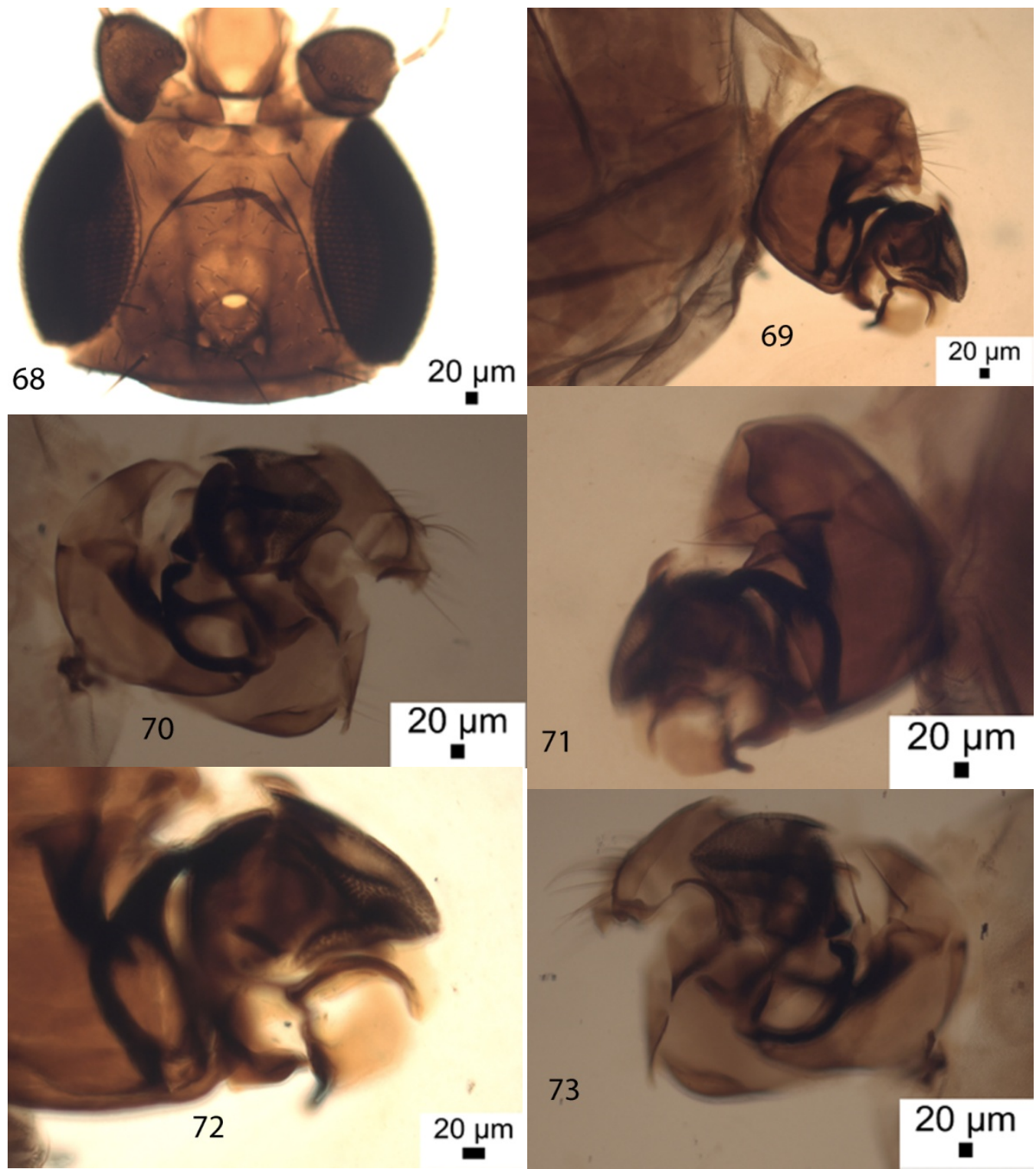

Figs 68-78. Gymnophora prescherweberae Disney, male. 68 - frons, 69-73 - hypopygium. 

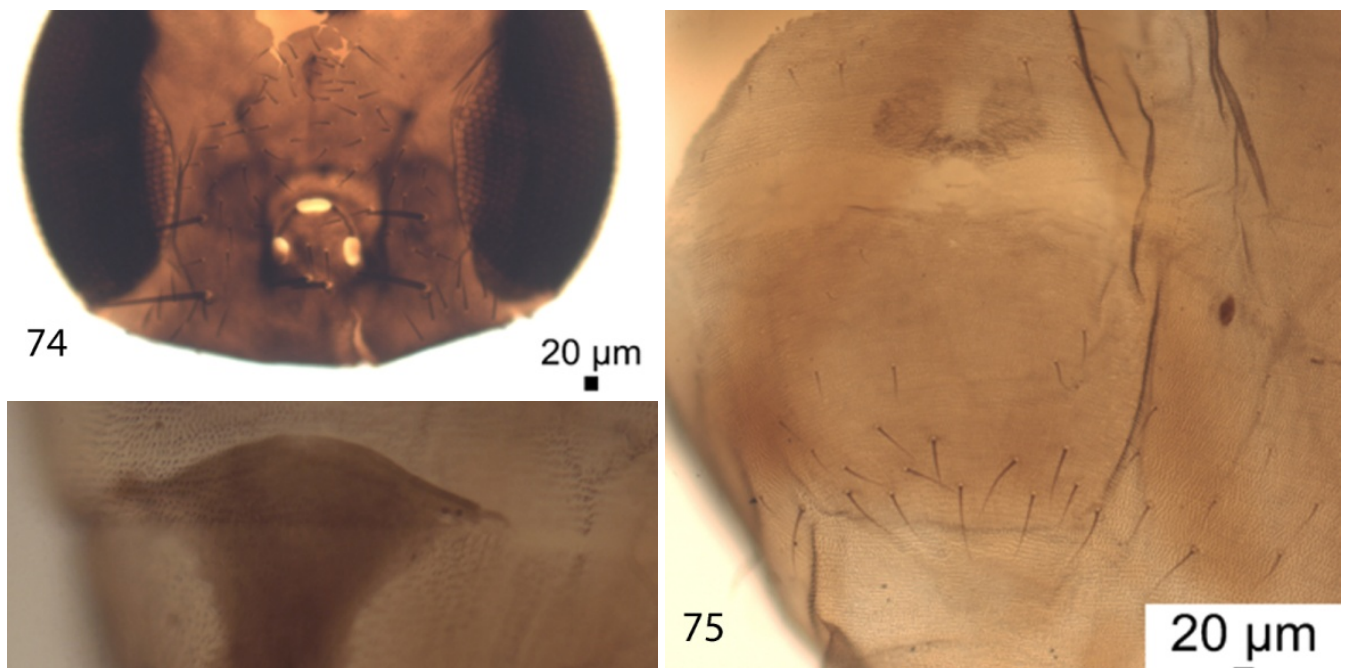

76

\section{$20 \mu \mathrm{m}$}

78

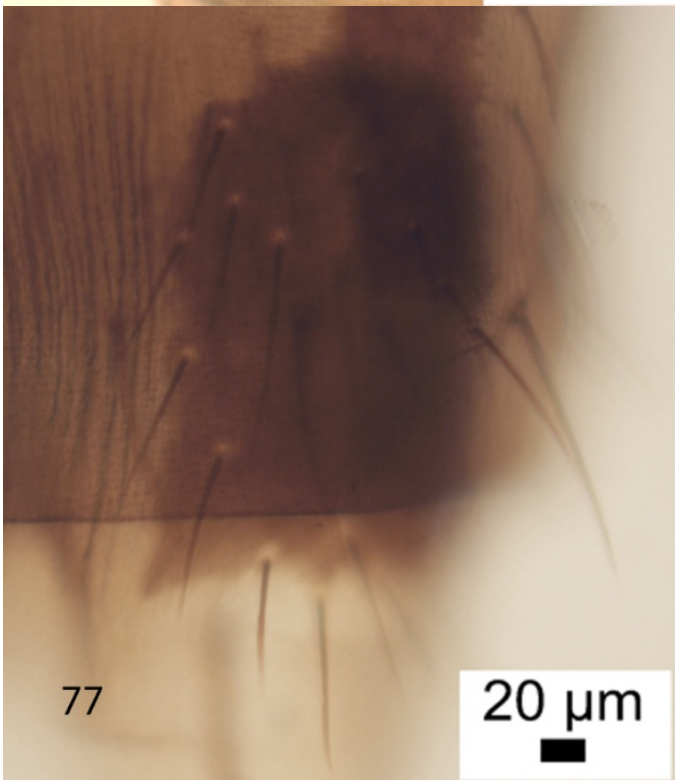

Figs 74-78. Gymnophora prescherweberae Disney, female. 74 - frons, 75 - abdominal tergites 5 \& 6 and DAGs, 76 tergite 7, 77 - tergite 8 , 78 - wing basal half.

\section{Gymnophora quartomollis Schmitz}

Gymnophora quartomollis Schmitz, 1920: 134.

(Figs 79-88)

A lectotype female from The Neterlands has been designated (Disney 1980). Other species have been confused with this species in the past. Females of $G$. forresteri have incorrectly been attributed to this species (e.g. Disney 1983, Disney \& Russell-Smith 2015 a, b, Mostovski \& Michailovskaya 2003). Schmitz's brief description of the female will not distinguish it from the newly recognized G. forresteri (above). The critical features of the true female are detailed below. 
It is worthy of note that a minority of the specimens of the large series examined possess small mediolateral bristles on the frons of varying degrees of robustness. These $\mathrm{M}-\mathrm{L}$ bristles are undoubtedly a plesiomorphic feature that has been lost in most specimens.

Female. Abdominal tergites 5 and 6 as Fig. 85. Tergite 8 as Fig. 86. Rear of sternum 8 as Fig. 87. Wing as Fig. 88.

Distribution. Widespread in Great Britain. Mainland Europe: from Finland, Norway to France and east to the Czech Republic and Hungary.

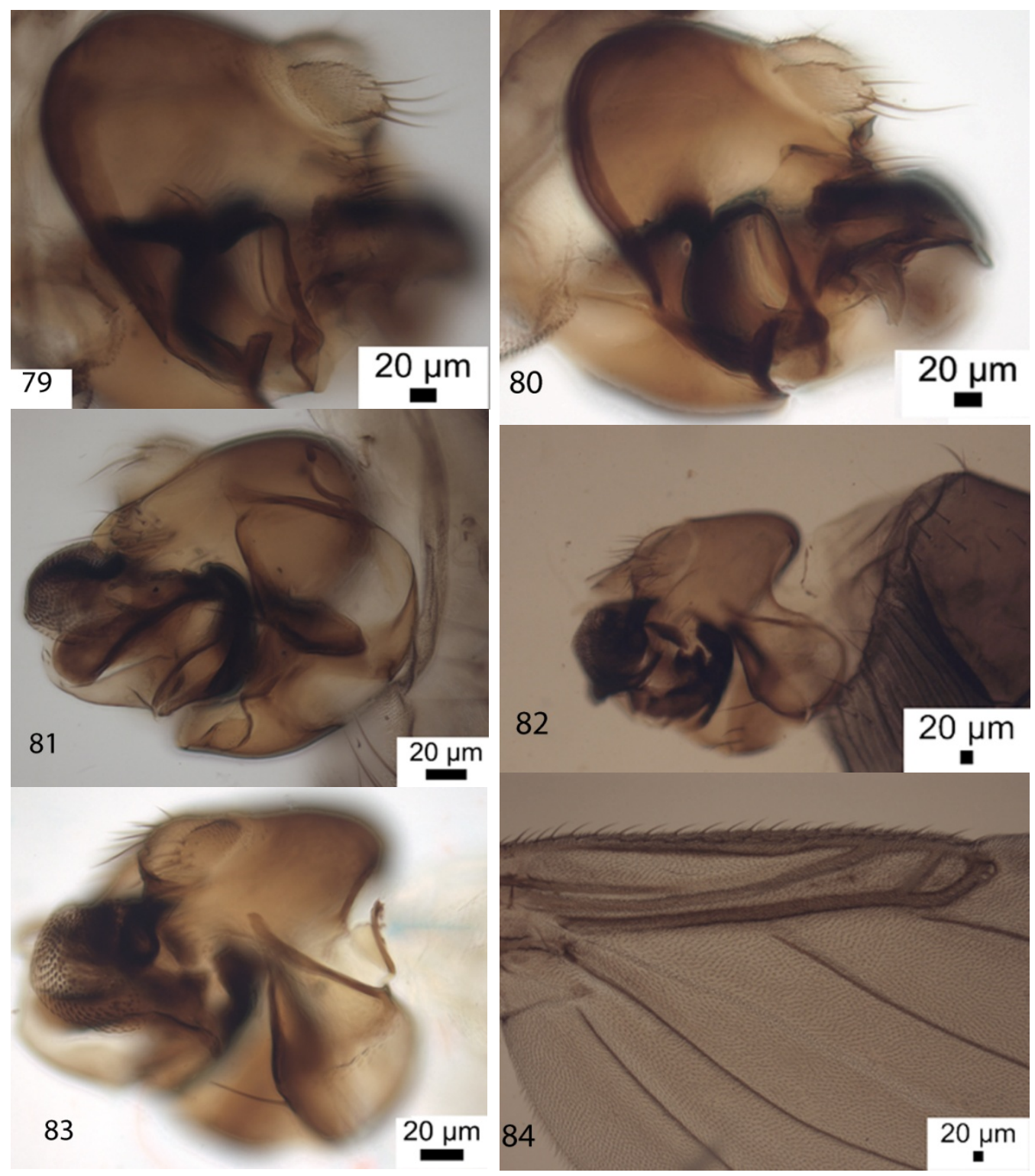

Figs 79-84. Gymnophora quartomollis Schmitz male. 79 - left face of epandrium, 80 - Left face of hypopygium, 81 right face of epandrium, 82 - right face of hypopygium, 83 - right lobe of hypandrium, 84 - basal half of wing. 


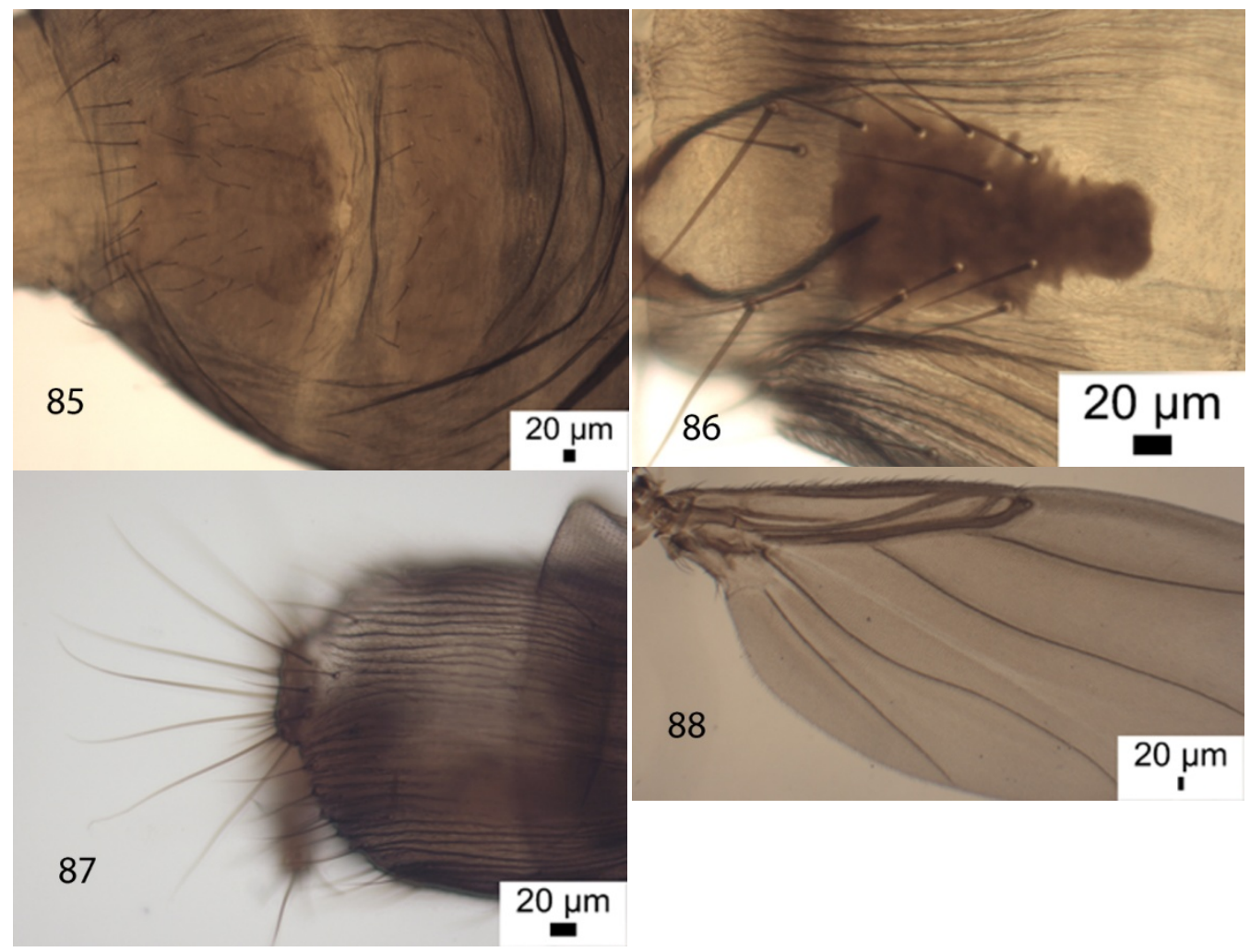

Figs 85-88. Gymnophora quartomollis Schmitz female. 85 - abdominal tergites 5 and 6, 86 - tergite 8, 87 - rear of sternum 8, 88 - basal half of wing.

\section{Gymnophora tyrolensis n. sp.}

(Figs 89-97)

Description. Male. Frons as Fig. 89. Postpedicels and palps as Fig. 90. With 2 bristles on the notopleuron and the oblique ridge with its posterior border black. Scutellum with the anterior pair of bristles about $0.10 \mathrm{~mm}$ long and the posterior pair about $0.13 \mathrm{~mm}$ long. Abdominal segment 6 as Fig. 91. Hypopygium as Figs 92-94. Legs light brown, with front legs palest. Front tarsus (Fig. 95) with posterodorsal hair palisades on segments 1 to 4 . Hind femur as Fig. 96. Wing (Fig. 97) 2.4-2.5 mm long. Costal index 0.48. Costal ratios $6.8: 2.1-2.2: 1$. Haltere knob pale gray.

Material examined. Holotype male, Austria, N. Tyrol, Karwendel (Engalm), 1190 m, edge of forest, water trap, 6-9 Aug 2004, S. Brenner (CUMZ 3-44).

Etymology. Named after the type locality.

Affinities. In the key to males by Mostovski \& Michailovskaya (2003) it runs to couplet 17. It is immediately distinguished from G. victoria Mostovski \& Michailovskaya whose oblique ridge of the notopleuron is pale. It differs from $M$. prescherweberae Disney by its lack of the mediolateral bristles on the frons and the very similar hypopygium differs in detail, notably the possession of a large process from the base of the left edge of the hypandrium (Fig. 93). 


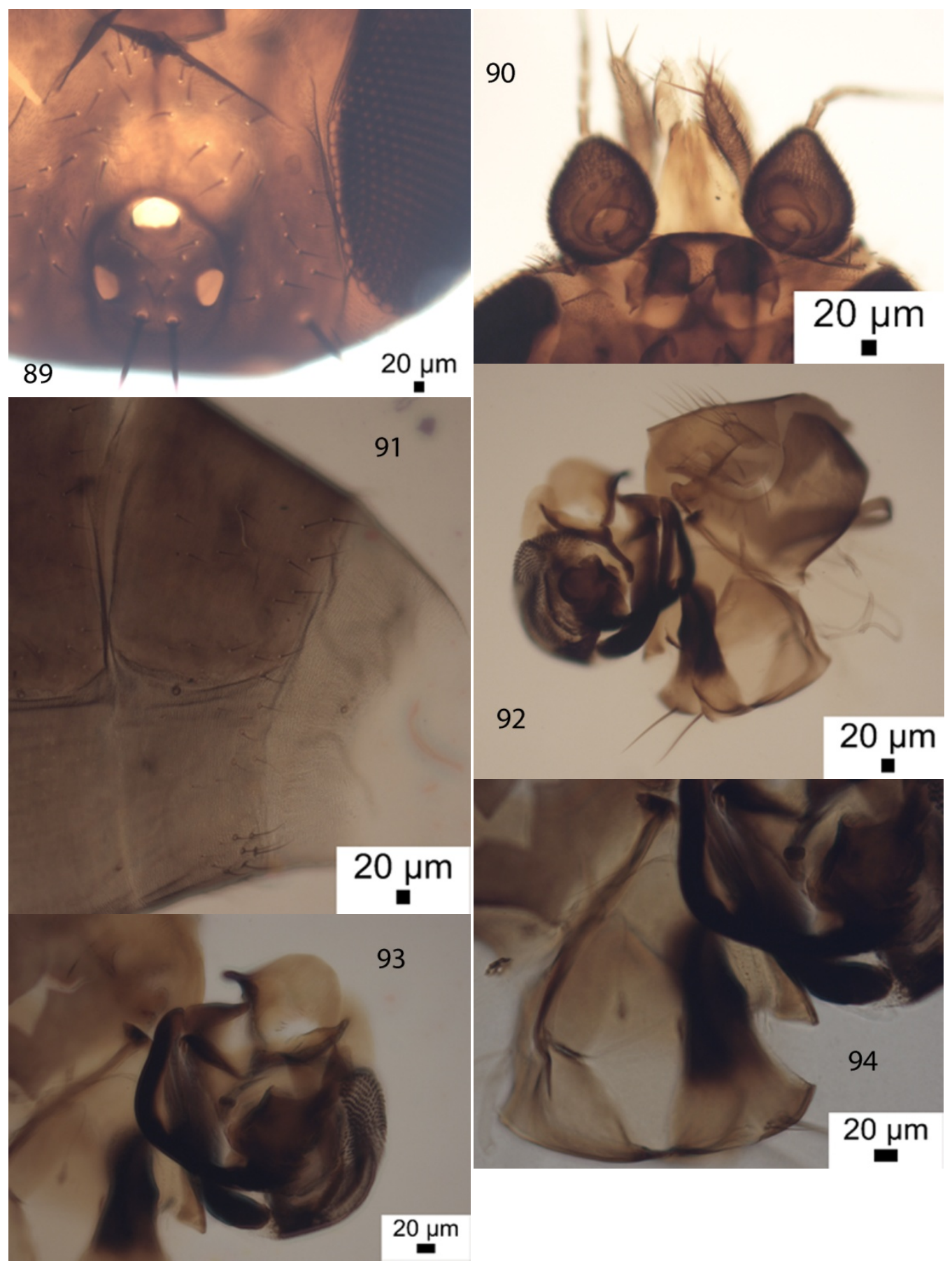

Figs 89-94. Gymnophora tyrolensis n. sp. male. 89 - frons, 90 - postpedicels and palps, 91 - abdominal segment 6, 92-94 - hypopygium. 

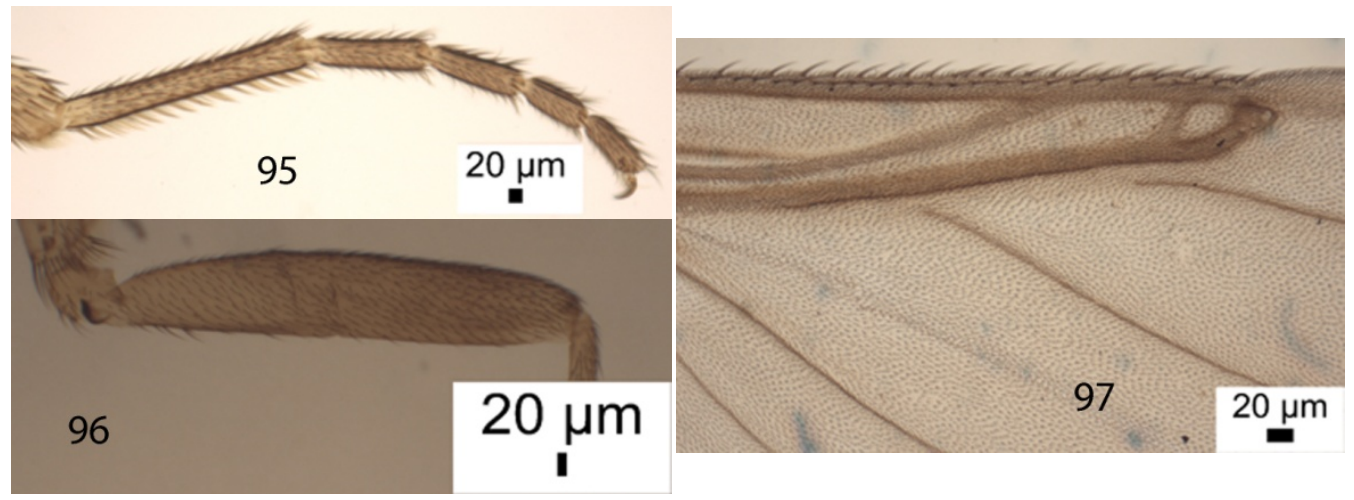

Figs 95-97. Gymnophora tyrolensis n. sp. male. 95 - front tarsus, 96 - hind femur, 97 - basal half of wing.

\section{Gymnophora winqvisti n. sp.}

(Figs 98-106)

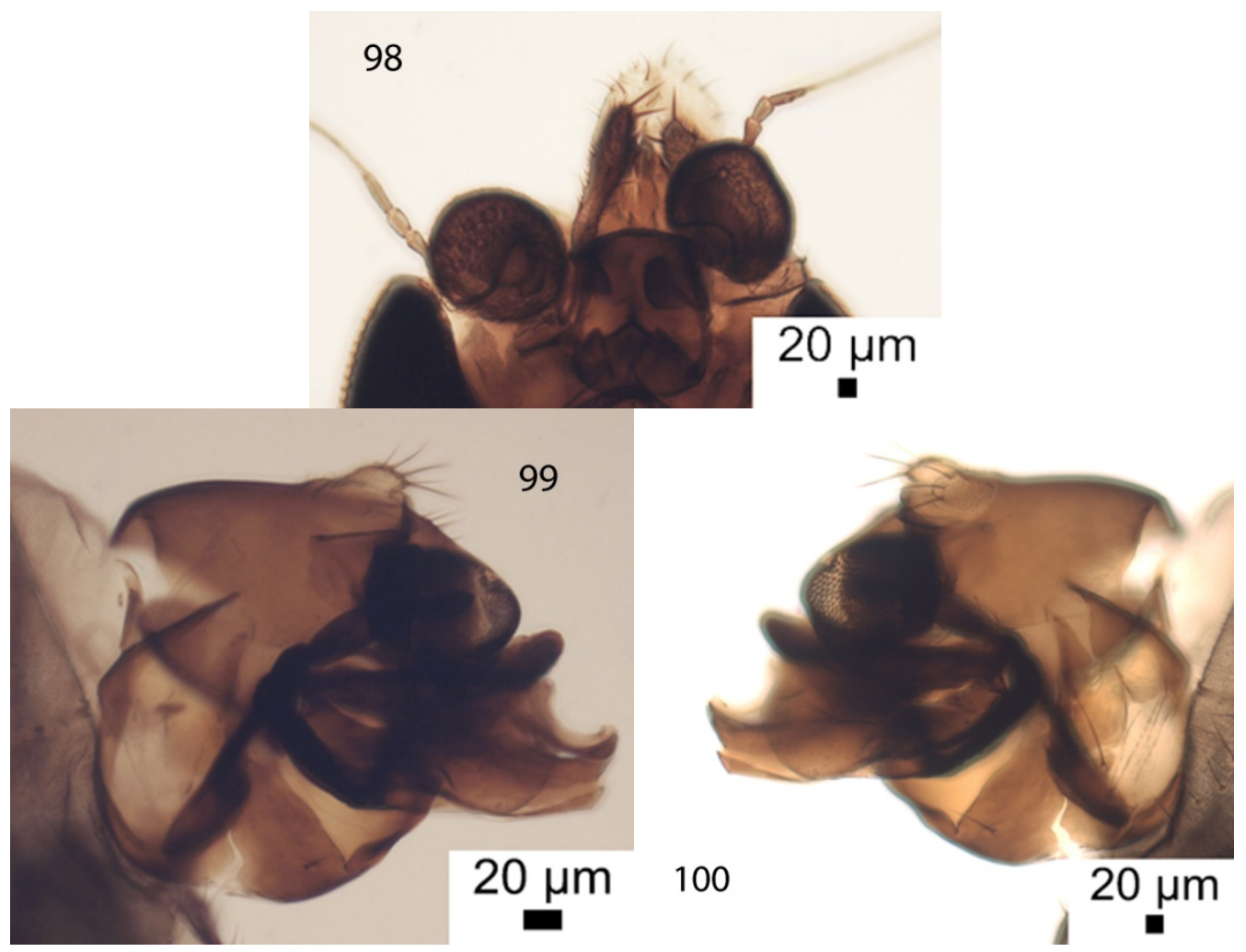

Figs 98-100. Gymnophora winqvisti n. sp. male: 98 - postpedicels and palps, 99 - left face of hypopygium, 100 - right face of hypopygium. 

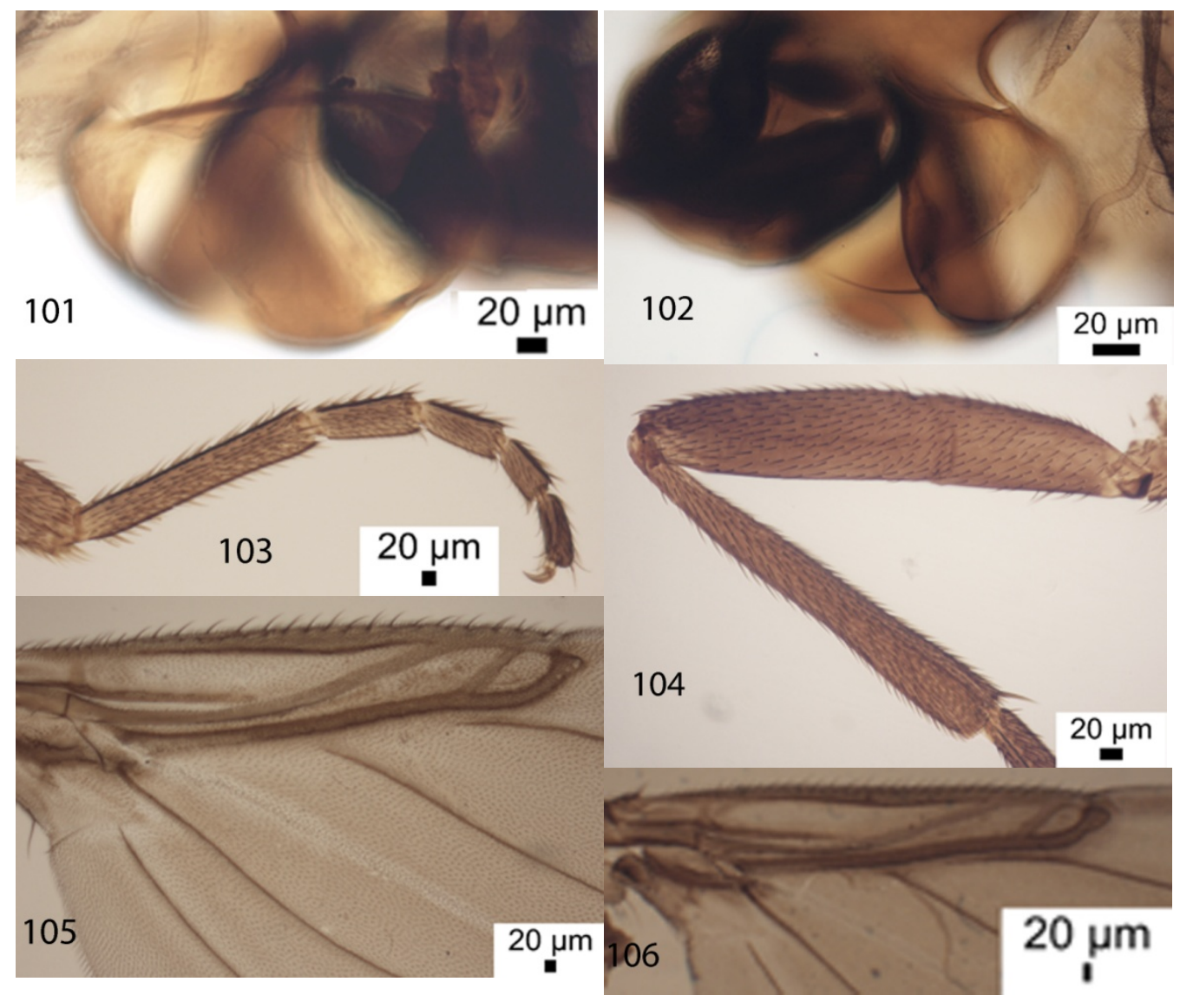

Figs 101-106. Gymnophora winqvisti n. sp. male: 101 - process from left edge of hypandrium, 102 - right hypandrial lobe, 103 - front tarsus, 104 - hind femur and tibia, 105 - basal half of wing of paratype,106 - detail of wing of holotype.

Description. Male. Frons lacks mediolateral bristles. Postpedicels and palps as Fig. 98. With 2 bristles on the notopleuron and the oblique ridge with its posterior border black. Scutellum with the anterior pair of bristles about $0.06 \mathrm{~mm}$ long and the posterior pair about 0.07 mm long. Hypopygium as Figs 99-102. Legs brown but not dark. Front tarsus (Fig. 103) with a posterodorsal hair palisade on segments 1 to 5 , but that on 5 does not extend the full length. Hind femur and tibia as Fig. 104. Wing (Figs 105 \& 106) 2.0-2.6 mm long. Costal index 0.46-0.49. Costal ratios $8.4-11.7: 1.7-2.4: 1$. The origin of vein 4 well before the level of the tip of vein 1 in the holotype (Fig. 106) bot not so in the paratype (Fig. 105). Haltere knob gray.

Material examined. Holotype male, Lkor: Savakoski. Yli-Nuorti 7524114: 3599141, 30 Jul-28 Sep 2015, Kaj Winqvist (CUMZ 34-188). Paratype male, Finland, Lkor: Pelkosenniemi, Kemihaara, 7445308: 3537275, 30 Jul-29 Sep 2015, Kaj Winqvist (CUMZ 34-187).

Etymology. The name refers to Kaj Winqvist the collector of the holotype.

Affinities. In the key by Mostovski \& Michailovskaya (2003) it runs to couplet 16 lead 2 or 17 lead 2. In the first case its hypopygium clearly differs from G. fastigorum Schmitz. In the second case it is immediately distinguished from G. victoria Mostovski \& Michailovskaya whose oblique ridge of the notopleuron is pale rather than dark, in addition its hypopygium differs. 
KEY TO SPECIES OF GYMNOPHORA

Males

1. Wing fully developed and costa extends only about half wing length (e.g. Fig. 38)

- Wing shortened so that costa extends at least nine tenths of wing length (Fig. 61)

Iapidicola (Bezzi)

2. Costa thicker than vein 1 along most of its length and last third of vein 1 with front edge parallel to hind margin of costa (Fig. 63) nigripennis Schmitz

- Basal veins of wing otherwise 3

3. The oblique ridge of the notopleuron (covering the orifice of the duct from the notopleural gland) is black (Fig. 23), contrasting with its fringe of microtrichia

- The notopleural ridge is pale (Fig. 1). (Hypopygium as Fig. 2. The small swelling before the end of costal section 1 as Fig. 3) arcuata (Meigen)

..4. Costal section 1 with a posterior swelling before its tip (Figs $28 \& 67) \quad$............................. 5

- Costal section 1 lacks this feature

5. Thick veins of wing as Fig. 28, with the hind margin of the tip of the swollen part of costal section 1 being almost parallel to the front margin of the tip of vein 1 . The elaborate hypopygium as Figs 24-26

distinctus n. sp.

- Not so

7. Costal section 2 longer than 3. Hypopygium as Figs $54-57$ integralis Schmitz

- C1 and 2 subequal (Fig. 67). Hypopygium otherwise

perpropinqua Mostovski \& Mikhailovskaya

8. Hypopygium (Figs 48-50) with a long, dark process from the base of the left edge of the hypandrium and a long pale process from its right side (Fig. 50). (Costal section 1 only gradually widening - Fig. 53)

healeyae Disney

- Hypopygium not thus

9. Hypopygium as Figs 7-11 with a posterolateral process of the epandrium as long as cercus. (Costal section 1 only very slightly widening - Fig. 14)

bifida n. sp.

- Hypopygium otherwise 10

10. Costal section 2 clearly longer than 3 (Figs 78 \& 97) 11

- Costal sections 2 and 3 subequal (e.g. Figs 38 \& 84) ... 12

11. A small pair of mediolateral bristles present on frons (Fig. 68). Hypopygium as Figs 69-73

prescherweberae Disney

- M-L bristles lacking. Hypopygium as Figs 92-94 tyrolensis n. sp.

12. Penis complex with paler lower processes protruding beyond the darker processes above (Figs 99 \& 100) winqvisti n. sp.

- Not so 13

13. The posterolateral lobes of the epandrium with 2-4 hairs (Figs $32 \& 35$ ). Other details of the hypopygium as Figs 31 \& 33-34 forresteri n. sp.

- The posterolateral lobes of the epandrium with at least 7 hairs (Figs 79 \& 81). Other details of the hypopygium as Figs 80 \& 82-83, the right hypandrial lobe having a dorsally diccсссссссссссссссссссссrected tapered process (Fig. 83). (Basal half of wing as Fig. 84)

quartomollis Schmitz

\section{Females}

1. Wing fully developed and costa extends only about half wing length (Fig. 38)

- Wing shortened so that costa extends at least nine tenths of wing length (Figs 61 \& 62) ....... 
2. The oblique ridge of the notopleuron (covering the orifice of the duct from the notopleural gland) is black, contrasting with its fringe of pale microtrichia 3

- The notopleural ridge is pale (Fig. 1). Abdominal tergite 3 reduced and T4 and T5 absent (Fig. 4) arcuata (Meigen)

3. Costa thicker than vein 1 along most of its length and last third of vein 1 with front edge parallel to hind margin of costa (Fig. 63) nigripennis Schmitz

- Costal section 1 not thus 4

4. Costa beyond basal quarter of section 1 remains of even width to tip ................................ 5

- Not so

5. Frons with mediolateral bristles (Fig. 74). Wing base as Fig. 78. (Abdominal tergites 3-5 absent, T7 as Fig. 76. T8 larger than usual - Fig. 77. When discernible the DAGs are pale - Fig. 75) prescherweberae Disney

- Frons without mediolateral bristles. Wing base with CS2 clearly even longer than CS3 (Fig. 97)

tyrolensis n. sp.

6. The origin of vein 4 is before the level of the tip of vein 1 (Fig. 106) winqvisti n. sp.

- Vein 4 originates at about the level of the fork of vein 3 7

Note. In the paratype of $G$. winqvisti the origin of vein 4 does not extend so far. Until its female is described it cannot be keyed out below.

7. Orifice of the common duct from the internal dorsal abdominal glands (DAGs) discharges into a large, dark bordered chamber in front of the constricted anterior part of abdominal tergite 6 (Figs 58-59) integralis Schmitz

- Chamber embracing orifice of common duct from DAGs smaller and less conspicuous and T6 without constriction in anterior fifth

8. Tergites 5-6 and DAGs as Fig. 51. Lobes at rear of sternum 8 as Fig. 52. Frons with mediolateral bristles present. Wing base as Fig. 53 healeyae Disney

- Without this combination 9

9. Dorsal abdominal glands as Fig. 17. Tergite 7 as Fig. 18. Sternum 8 as Fig. 19 (Wing base as Fig. 20) bifida n. sp.

- Not so 10

10. Lobes at rear of sternum 8 fused into a single, median lobe (Figs $44 \& 87$ ) 11

- S8 lobes well separated (Fig. 66). (T7 as Fig. 64. T8 as Fig. 65)

perpropinqua Mostovski \& Mikhailovskaya

11. Tergite 8 shorter (Fig. 42 \& 43). Sternum 8 lobe with numerous long bristles (Fig. 44)

forresteri n. sp.

- T8 longer (Fig. 86). S8 lobe with fewer long bristles (Fig. 87) quartomollis Schmitz

\section{COMMENT}

The correct association of the males and females of a species is best achieved by the procurement of mating pairs or in reared series. In the collection of British specimens in the Museum of Zoology in Cambridge 26 males and 11 females had been assigned to G. quartomollis prior to the recognition of $G$. forresteri as being distinct with regard to the very similar G. quartomollis. Of these 11 males and 10 females are now assigned to G. forresteri, so that only a single female of $G$. quartomollis has so far been confirmed for Britain. By contrast 36 males and 8 females of a new series from Finland are G. quartomollis. The associations of these males and females was based on three samples from three different localities. It was these samples from Finland that allowed the recognition of the single female of this species from Britain and that specimens previously referred to this species were in fact G. forresteri. 


\section{ACKNOWLEDGEMENTS}

I am grateful to the Naturalis Biodiversity Center, Leiden for the loan of the pinned lectotype and a paratype of G. quartomollis and to Luc Willemse for allowing me to remount them on slides. My work on Phoridae is currently funded by the Balfour-Browne Trust (University of Cambridge).

\section{REFERENCES}

BEzZI M. 1922. Un Diptero subattero appartenente ad uno Nuevo gernere di Foridi non myrmecophili. Bollettino della Societa Entomologica Italiana 54: 113-117.

Brown B. V. 1987a. Revision of the Gymnophora (Diptera: Phoridae) of the Holarctic Region: classification, reconstructed phylogeny and geographic history. Systematic Entomology 12: 271-304.

BROWN B.V. 1987b. Classification, reconstructed phylogeny and geographic history of the Neotropical phorid flies of the genus Gymnophora (Diptera: Phoridae). Journal of Natural History 21: 1477-1524.

Brown B.V. 1989. Testing phylogenetic hypotheses: new species of Gymnophora Macquart (Diptera: Phoridae) from Japan and Nepal, with an updated world classification. Canadian Journal of Zoology 67(10): 2543-2556.

Brown B.V. 1998. New species and records of Gymnophora Macquart (Diptera: Phoridae) from southeast Asia. Contributions in Science (Natural History Museum of Los Angeles County) 471: 1-14.

DisNeY R. H. L. 1980. A new species of Gymnophora Macquart (Diptera, Phoridae) from Yorkshire and Durham. Naturalist, Hull 105(955): 125-131.

Disney R. H. L. 1983. Scuttle Flies - Diptera, Phoridae (except Megaselia). Handbooks for the Identification of British Insects 10 (6): 1-81.

Disney R. H. L. 1997. A new species of Gymnophora (Dipt., Phoridae) from Germany. Entomologist's Monthly Magazine 133: 73-75.

DISNEY R. H. L. 2001, The preservation of small Diptera. Entomologist’s Monthly Magazine 137: 155-159.

DisNeY R. H. L. 2009. Scuttle flies (Diptera: Phoridae) from the Falkland Islands. Entomologist's Monthly Magazine 145: $125-128$.

DiSNEY R. H. L. 2015. An updated description of the montane Gymnophora lapidicola (Bezzi) (Diptera: Phoridae) that is flightless in both sexes. Fragmenta Faunistica 58 (1): 37-42.

Disney R. H. L. \& Russell-Smith A. 2015a. Additions to the British list of Megaselia Rondani (Diptera: Phoridae), including two new species, from the crowns of ancient pollarded trees, Journal of Natural History 45(25-26): 1599-1626.

Disney R. H. L. \& RuSSELl-Smith A. 2015b. Further records of Megaselia Rondani (Diptera: Phoridae) including two new species, from the crowns of ancient pollarded trees in England. Entomologist's Monthly Magazine 151: 169-175.

FALLÉn C. F. 1823. Phytomyzides et Ochtididae Sveciae. Lundae. 10 pp.

GHIDINi G. M. 1934. Descrizione della femmina di Gymnophora (Capraephora) lapidicola Bezzi. Bollettino della Societa Entomologica Italiana 66: 130-136.

Haliday A. H. 1833. Catalogue of Diptera occurring about Holywood in Downshire. Entomological Magazine 1: $147-180$

LIU G. 2001. A Taxonomic Study of Chinese Phorid Flies Diptera: Phoridae (Part 1). China: Neupress. 292 pp.

LundBecK W. 1922. Diptera Danica Part VI Pipunculidae, Phoridae. London: Wesley.

MACQUART J. 1835. Histoire naturelle des insectes. Diptères. In: RoRET N. E. (ed.), Collections des Suites à Buffon, Paris 2 (IV): 1-703.

MEIGEN J. W. 1830. Systematische Beschreibung der bekannten Europäischen zweiflügeligen Insekten. Bd. 6. Schulzische Buchhandlung, Hamm, XI+401 pp.

MichailovsKaya M. V. 1997. A review of the genus Gymnophora Macquart (Diptera, Phoridae) from the Russian far east. Far Eastern Entomologist 45: 1-8.

Michailovskaya M. V. 2004a. Scuttle Flies (Diptera, Phoridae) of the Far East of Russia. Russian Academy of Sciences Far Eastern Branch. Vladivostok, Dalnauka. 150 pp. [In Russian]

Michailovskaya M. V. 2004b. 31. Diptera. 60. Cem. Phoridae, pp 9-40. In Key to the Insects of Russian Far East. Vol. VI. Diptera and Siphonaptera. Pt 3. Vladivostok, Dalnauka. 659 pp. [In Russian]

Mostovski M. B. \& MichailovskAyA M. V. 2003 A review of Palaearctic Gymnophora Macquart (Diptera: Phoridae), with description of new species. European Journal of Entomology 100: 153-165.

SCHMITZ H. 1920. Die Phoriden von Holländisch Limburg mit Bestimmungstabellen aller bisher kenntlich beschrieben europäischen Phoriden. IV. Teil. Jaarboek Natuurhistorisch Genootschap in Limburg 1919: 91-153.

SCHMITZ H. 1926. Untersuchungen an Phoridentypen. Natuurhistorisch Maandblad 15: 19-24, 43-48, 55-57.

Schmitz H. 1929. Revision der Phoriden. Berlin: Ferdinand Dümmler. 212 pp + Tafel I and II.

SCHMITZ H. 1952. Über W. Lundbecks Sammlung und Beschreibung Dänischer Phoriden. Entomologiske Meddelelser 26: 350-37. 


\section{STRESZCZENIE}

[Systematyczny przegląd europejskich gatunków z rodzaju Gymnophora Macquart (Diptera: Phoridae), wraz z opisem pięciu gatunków nowych dla nauki]

W pracy opisano pięć nowych dla nauki gatunków zadrowatych z rodzaju Gymnophora (G. bifida n. sp., G. distinctus n. sp., G. forresteri n. sp, G. tyrolensis n. sp., G. winqvisti n. sp.) z obszaru Europy. Ogółem z Europy zostało wykazanych 13 gatunków zadrowatych z rodzaju Gymnophora. Każdy z gatunków został zilustrowany za pomocą kolorowych fotografii według kluczowych cech taksonomicznych. Opisy gatunków uwzględniają dane o występowaniu taksonów. Praca zawiera aktualny klucz do oznaczania europejskich gatunków Gymnophora. W komentarzu taksonomicznym autor zwraca uwage na znaczenie jednoczesnego pozyskiwania obu płci zadrowatych albo w okresie godowym albo z hodowli, aby uniknąć niewłaściwego zestawienia samic i samców różnych gatunków (vide G. quartomollis and G. forresteri). 